\title{
Investigating the spatio-temporal variability in groundwater and surface water interactions: a multi-technique approach
}

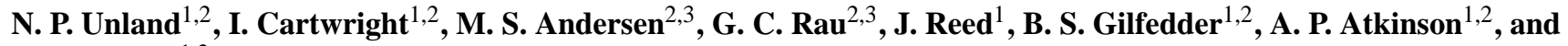 \\ H. Hofmann ${ }^{1,2}$ \\ ${ }^{1}$ School of Geosciences, Monash University, Clayton, Vic. 3800, Australia \\ ${ }^{2}$ National Centre for Groundwater Research and Training, G.P.O. Box 2100, Flinders University, \\ Adelaide, SA 5001, Australia \\ ${ }^{3}$ Connected Waters Initiative Research Centre (CWI), School of Civil and Environmental Engineering, University of New \\ South Wales, Sydney, NSW 2093, Australia
}

Correspondence to: N. P. Unland (nicolaas.unland@monash.edu)

Received: 19 February 2013 - Published in Hydrol. Earth Syst. Sci. Discuss.: 22 March 2013

Revised: 16 July 2013 - Accepted: 29 July 2013 - Published: 6 September 2013

\begin{abstract}
The interaction between groundwater and surface water along the Tambo and Nicholson rivers, southeast Australia, was investigated using ${ }^{222} \mathrm{Rn}, \mathrm{Cl}$, differential flow gauging, head gradients, electrical conductivity (EC) and temperature profiles. Head gradients, temperature profiles, $\mathrm{Cl}$ concentrations and ${ }^{222} \mathrm{Rn}$ activities all indicate higher groundwater fluxes to the Tambo River in areas of increased topographic variation where the potential to form large groundwater-surface water gradients is greater. Groundwater discharge to the Tambo River calculated by $\mathrm{Cl}$ mass balance was significantly lower $\left(1.48 \times 10^{4}\right.$ to $1.41 \times 10^{3} \mathrm{~m}^{3}$ day $^{-1}$ ) than discharge estimated by ${ }^{222} \mathrm{Rn}$ mass balance $\left(5.35 \times 10^{5}\right.$ to $9.56 \times 10^{3} \mathrm{~m}^{3}$ day $\left.^{-1}\right)$ and differential flow gauging $\left(5.41 \times 10^{5}\right.$ to $6.30 \times 10^{3} \mathrm{~m}^{3}$ day $\left.^{-1}\right)$ due to bank return waters. While groundwater sampling from the bank of the Tambo River was intended to account for changes in groundwater chemistry associated with bank infiltration, variations in bank infiltration between sample sites remain unaccounted for, limiting the use of $\mathrm{Cl}$ as an effective tracer. Groundwater discharge to both the Tambo and Nicholson rivers was the highest under high-flow conditions in the days to weeks following significant rainfall, indicating that the rivers are well connected to a groundwater system that is responsive to rainfall. Groundwater constituted the lowest proportion of river discharge during times of increased rainfall that followed dry periods, while groundwater constituted the highest proportion of river discharge under baseflow conditions (21.4\% of the Tambo in April 2010 and $18.9 \%$ of the Nicholson in September 2010).
\end{abstract}

\section{Introduction}

Constraining the interaction between groundwater and rivers is important for calculating water balances and sustainable levels of water extraction (Tsur and Graham-Tomasi, 1991), maintaining healthy river ecology (Boulton, 1993; Krause et al., 2007; Lambs, 2004), understanding biogeochemical reactions at the groundwater-surface water interface (Peyrard et al., 2011; Sophocleous, 2002; Woessner, 2000) and determining the source and fluxes of nutrients and solutes carried by rivers. In order to estimate groundwater discharge to rivers and to define gaining and losing reaches, a number of physical, chemical and numerical methods have been developed (Kalbus et al., 2006).

Differential flow gauging uses the difference in river discharge at two points along a reach in order to calculate net gains or losses along that stretch (Cey et al., 1998; Harte and Kiah, 2009; McCallum et al., 2012; Ruehl et al., 2006). Discharge is usually measured under baseflow conditions where runoff is negligible, allowing the net groundwater discharge or recharge to be calculated once evaporative losses are accounted for. While gauging stations are usually spaced far apart and often overlook variations at smaller spatial scales, long time series of measurements are commonly available, allowing for analysis of temporal trends and comparison with other methods (McCallum et al., 2013).

As groundwater temperature is commonly higher than that of surface water in winter and lower in summer (Anibas et al., 2009), measurement of temperature in rivers and streambeds can be used to identify the gaining and losing 
reaches (Anderson, 2005; Andersen and Acworth, 2009; Anibas et al., 2011; Rau et al., 2010; Silliman and Booth, 1993). While quantification of water fluxes using temperature requires detailed subsurface temperature measurements over time, temperature mapping of rivers is a simple and effective method of identifying gaining and losing reaches (Becker et al., 2004). Similarly, if groundwater has a significantly different electrical conductivity (EC) to surface water, changes in river EC can be used to quantify the influx of groundwater (Cartwright et al., 2011; Cey et al., 1998; McCallum et al., 2012). The advantage of along-river temperature/EC surveying is that it allows data to be obtained at a higher spatial resolution than flow gauging or discrete sampling for chemical analysis.

Geochemical tracers including major ions, stable isotopes and radiogenic isotopes have been used to estimate groundwater fluxes in gaining rivers (Cartwright et al., 2008, 2010, 2011; Cook, 2012; Cook et al., 2003, 2006; Durand et al., 1993; Genereux et al., 1993; Genereux and Hemond, 1990; Lamontagne et al., 2005, 2008; Lamontagne and Cook, 2007; Mullinger et al., 2007, 2009; Négrel et al., 2003; Rhode, 1981; Ribolzi et al., 2000; Stellato et al., 2008). The utility of each of these tracers depends on a variety of factors including the difference between the concentration of the tracer in groundwater compared to surface water, its spatial and temporal variability, the accurate characterisation of its sources and sinks, and the potential for it to change by processes such as evaporation, precipitation, radioactive decay, degassing, or biogeochemical reactions. However after such processes are accounted for, chemical tracers are useful in assessing groundwater fluxes, as runoff does not impact flux estimates and spatial analyses are only limited by sampling frequency.

${ }^{222} \mathrm{Rn}$ is produced by the decay of ${ }^{226} \mathrm{Ra}$ in the ${ }^{238} \mathrm{U}$ to ${ }^{206} \mathrm{~Pb}$ decay series. Since ${ }^{226} \mathrm{Ra}$ activities are high in minerals, ${ }^{222} \mathrm{Rn}$ activities in groundwater increase as it achieves secular equilibrium with the ${ }^{226} \mathrm{Ra}$ in minerals over periods of approximately 2-3 weeks (Cook, 2012). After groundwater discharges to a surface water body, degassing and radioactive decay will reduce ${ }^{222} \mathrm{Rn}$ activities, resulting in surface water activities that are usually 2 to 3 orders of magnitude lower than those in groundwater (e.g. Cook, 2012; Cook et al., 2006). The use of ${ }^{222} \mathrm{Rn}$ as a groundwater tracer has increased over the last two decades as methods for its measurement in the field have improved (Burnett et al., 2010; Cartwright et al., 2011; Cook et al., 2003; Ellins et al., 1990; Genereux and Hemond, 1990; Gilfedder et al., 2012; Hofmann et al., 2011; Mullinger et al., 2007, 2009; Santos and Eyre, 2011). The short half-life (3.82 days) and degassing of ${ }^{222} \mathrm{Rn}$ from surface water makes it a particularly valuable groundwater tracer, as elevated ${ }^{222} \mathrm{Rn}$ activities will only occur close to zones of groundwater discharge.

The effectiveness of ${ }^{222} \mathrm{Rn}$ as a groundwater tracer can be limited by poorly defined groundwater end members and low surface water concentrations which can lead to high analytical uncertainties. The uncertainties associated with groundwater end members can be reduced by combining groundwater measurements with laboratory experiments in which the ${ }^{222} \mathrm{Rn}$ activity of water in equilibrium with the river sediments is determined (Burnett et al., 2008; Cook et al., 2006; Corbett et al., 1998; Martens et al., 1980; Peterson et al., 2010). Recent studies have also focussed on better quantifying processes such as hyporheic exchange and gas transfer, making the use of ${ }^{222} \mathrm{Rn}$ more reliable (Cook et al., 2006; Lamontagne and Cook, 2007; Mullinger et al., 2007).

This study uses major ion chemistry, differential flow gauging, and ${ }^{222} \mathrm{Rn}$ activities to calculate groundwater fluxes to the Nicholson and Tambo rivers and assess how groundwater fluxes vary in response to seasonal changes in rainfall and river discharge. These techniques are combined with EC and temperature mapping to evaluate the detailed spatial variability of groundwater discharge. By combining differential flow gauging with chemical mass balance, errors in groundwater estimates due to the presence of losing reaches or runoff during periods of rainfall can be accounted for. By combining these techniques with temperature and EC surveys, the applicability of each technique can be evaluated, and the variability in groundwater-surface water interaction on a fine spatial scale can be investigated. Furthermore, by conducting the study on two rivers in the same catchment, controls on the gaining and losing behaviour of neighbouring rivers can be investigated. Studies that employ multiple techniques for such investigations have been historically less common than research focussed on one or two methods, and can provide additional and more robust information for groundwater-surface water studies (Cox et al., 2007).

\section{Study area}

The Tambo and Nicholson rivers occur within the Tambo River Basin (Fig. 1), which has a total surface area of $\sim 4200 \mathrm{~km}^{2}$. These are perennial rivers that drain southwards from the Eastern Victorian Uplands across the Gippsland Basin to Lake King (a saline coastal lake connected to the Tasman Sea). The lake system is affected by tidal forcing which propagates into the lower sections of both the Nicholson and the Tambo rivers, forming estuarine sections that extend $\sim 15 \mathrm{~km}$ upstream from the lake during low-flow conditions. The river sections do not contain significant tributaries, and minor creeks were not flowing during the sampling campaigns.

Average annual precipitation in the catchment is $\sim 705 \mathrm{~mm}$, increasing from $655 \mathrm{~mm}$ in the upper catchment to $777 \mathrm{~mm}$ in the mid- to lower reaches. Precipitation is relatively evenly distributed throughout the year, with slightly higher than average monthly rainfall during October to December (Bureau of Meteorology, 2012). Annual evapotranspiration rates decrease from 600 to $700 \mathrm{~mm}$ in the upper catchment to 500 to $600 \mathrm{~mm}$ in the lower catchment. During the study period, evaporation ranged from $6.7 \times 10^{-3} \mathrm{~m} \mathrm{day}^{-1}$ in April 2011 to $3.6 \times 10^{-3} \mathrm{mday}^{-1}$ 


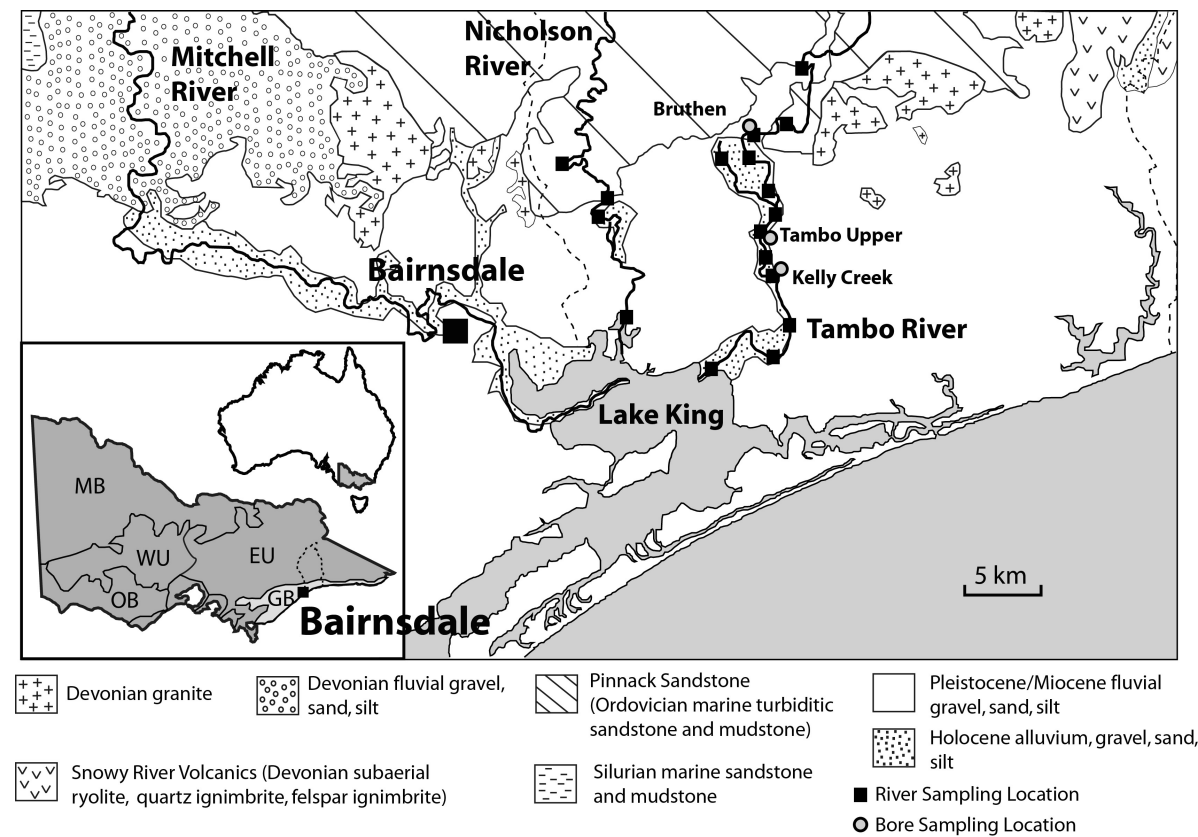

Fig. 1. Map of the Tambo River Basin (dashed line) with sampling locations on Tambo and Nicholson rivers, and local surface geology (modified from Jolly, 1997). GB = Gippsland Basin, EU = Eastern Victorian Uplands, WU = Western Victorian Uplands, OB = Otway Basin, $\mathrm{MB}=$ Murray Basin.

during August 2011 (Bureau of Meteorology, 2012). Approximately $80 \%$ of the catchment area is covered by forest and woodland, with the remainder dominated by cattle grazing on river floodplains (Department of Agriculture, Fisheries and Forestry, 2006).

The geology of the northern region of the Tambo River Basin is dominated by Ordovician gneisses and schists and Silurian-Devonian granites that form a fractured rock aquifer (Chaplin, 1995; Jolly, 1997; Vandenberg and Stewart, 1992). The southern section of the basin is dominated by Tertiary sands and gravels (of the Haunted Hills Gravels and Baxter Sandstone) and Quaternary sands, silts, and calcareous sands of the Shepparton Formation (Fig. 1). Various dune/beach deposits, alluvium and colluvium are locally present with the Tertiary and Quaternary units. While very little is known about the bedrock aquifers in the area, the Tambo and Nicholson rivers flow through an Upper Tertiary aquifer of sands, gravels and clays in the lower catchment. In the study area, the Upper Tertiary aquifer contains groundwater with a total dissolved solids (TDS) content of 500 to $1000 \mathrm{mg} \mathrm{L}^{-1}$. The aquifer overlies middle and lower Tertiary aquifers that are dominated by calcareous sands, gravels, coal and basalt that contain groundwater with a TDS of 1000 to $3000 \mathrm{mg} \mathrm{L}^{-1}$.

\section{Methods}

\subsection{River surveys and flow gauging}

River discharge is measured at Sarsfield on the Nicholson River and at Ramrod Creek and Battens Landing on the Tambo River (Victorian Water Resource Warehouse, 2012). In the absence of runoff, significant tributary inflows or changes in the storage of a river channel, the net groundwater flux to a river $\left(I_{N}\right)$ can be calculated from (Lerner et al., 1990)

$I_{\mathrm{N}}=Q_{\mathrm{d}}+E-Q_{\mathrm{u}}-P$,

where $Q_{\mathrm{d}}$ is the river discharge at the downstream site, $Q_{\mathrm{u}}$ is the river discharge at an upstream site, $E$ is direct evaporation and $P$ is direct precipitation (all terms have units of $\left.\mathrm{m}^{3} \mathrm{day}^{-1}\right)$.

The groundwater flux to the Tambo River was calculated using Eq. (1) and the difference in river discharge between Battens Landing and Ramrod Creek flow gauging stations. The difference in the timing of discharge events between the two stations was accounted for by time shifting the discharge of data of the Ramrod Creek gauging station so that discharge events matched (McCallum et al., 2013). When discharge events did not occur during sampling periods (i.e. baseflow conditions), the Ramrod Creek data were time-shifted using the distance between the stations and the river velocity (calculated using the discharge and river width and depth) to calculate the lag time. $I_{\mathrm{N}}$ estimates were based on the discharge 


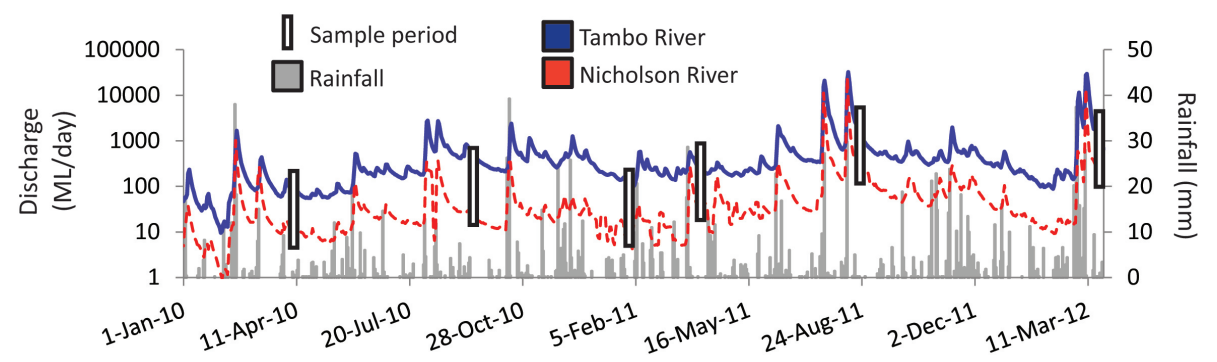

Fig. 2. Sampling frequency superimposed on river hydrographs (Tambo River $=$ Battens Landing station 223209, Nicholson River $=$ Sarsfield gauging station 223210) and rainfall in the Tambo Catchment (Bairnsdale Airport, station 85279).

data for a period of $\sim 48 \mathrm{~h}$ leading up to and including sampling. Direct evaporation and rainfall were calculated using the surface area of the river and data from the Bairnsdale Airport weather station (Bureau of Meteorology, 2012).

Run-of-the-river continuous surface water EC/temperature surveys were conducted during the February 2011 and March 2012 sampling campaigns using a Schlumberger CTD-Diver and an Aqua TROLL 200 logger with a precision of $\pm 1 \%$ (EC) and $\pm 0.1^{\circ} \mathrm{C}$ (temperature). Elevation and location during the surveys were recorded using a Trimble DGPS with a precision of $<0.02 \mathrm{~m}$. The elevation of bores and the Tambo River adjoining the bores was measured using a Trimble DGPS with a precision of $<0.01 \mathrm{~m}$ in February 2011. Elevation of the river in subsequent campaigns was interpolated from river height data at the Battens Landing and Ramrod Creek gauging stations. Groundwater elevations in bores were measured using an electronic water tape during the sampling campaigns. All elevations are reported in metres relative to the Australian Height Datum (AHD). Groundwater-surface water gradients were calculated at Bruthen and Tambo Upper using the measured groundwater elevations of the bore closest to the river and river, with an uncertainty of $\pm 0.01 \mathrm{~m}$. Gradients were only calculated at Kelly Creek during February 2011 as upstream gauging does not account for the tidal nature of the location and could not be used to interpolate river height in subsequent campaigns. River depth and width in upstream reaches were measured in the field using a tape measure. The width of wider downstream reaches was estimated using Google Earth with an uncertainty of $<1.0 \mathrm{~m}$.

\subsection{Sampling}

Investigations were carried out between the upper catchment and the coastal plain of the Tambo and Nicholson rivers (Fig. 1). Six sampling campaigns were conducted on a $\sim 40 \mathrm{~km}$ section of the Tambo River and a $\sim 21 \mathrm{~km}$ section of the Nicholson River between April 2010 and March 2012. Surface and groundwater sampling took place over a 1- to 2-day period. Sample locations are designated by distance upstream from Lake King. There are 12 sampling locations on the Tambo River and 5 on the Nicholson River. Sampling in April 2010 was conducted at near-baseflow conditions, while sampling in September 2010 took place during the recession of a minor discharge event (Fig. 2). Sampling in February 2011 occurred during a discharge event, while the April 2011 campaign was conducted during low-flow conditions after a minor discharge event. Sampling campaigns conducted during August 2011 and March 2012 both took place during the recession of major flood events. Groundwater measurement and sampling were conducted in conjunction with river sampling but excluded April 2010 and September 2010 campaigns, as bores were still under construction at these times. Groundwater was sampled at three locations along the Tambo River. Three bores were sampled at Bruthen $(28.5 \mathrm{~km})$, two at Tambo Upper $(20.2 \mathrm{~km})$ and 1 at Kelly Creek (13.8 km). The bores were installed within $20 \mathrm{~m}$ of the river at 6 to $7 \mathrm{~m}$ depth below surface, with screened sections 1 to $1.5 \mathrm{~m}$ in length. Bores were sampled using an impeller pump set at the screened section, and at least 3 bore volumes were pumped before samples were collected.

\subsection{Sample preparation and analysis}

EC was measured in the field using a calibrated TPS pH/EC meter. Water samples were preserved in the field by refrigeration in air-tight polyethylene bottles. Anion concentrations were measured on samples that were filtered through $0.45 \mu \mathrm{m}$ cellulose nitrate filters using a Metrohm ion chromatograph at Monash University, Clayton; precision estimated by replicate analysis is $\pm 2 \%$. Cation concentrations were measured on filtered samples that were acidified to $\mathrm{pH}<2$ using twicedistilled $16 \mathrm{M}$ nitric acid by a Varian Vista ICP-AES (inductively coupled plasma-atomic emission spectroscopy) at the Australian National University or at Monash University, Clayton, using a Thermo Finnigan X series II, quadrupole ICP-MS. Drift during ICP-MS (inductively coupled plasmamass spectroscopy) analysis was corrected using internal Sc, $\mathrm{Y}$, In and Bi standards, and replicate analyses indicate a precision of $\pm 5 \%$. The activity of ${ }^{222} \mathrm{Rn}$ in water samples was measured using a RAD-7 radon-in-air detector by the method outlined in Burnett and Dulaiova (2006) and is reported in $\mathrm{Bq} \mathrm{m}^{-3} \cdot{ }^{222} \mathrm{Rn}$ was degassed from $500 \mathrm{~mL}$ of water for $5 \mathrm{~min}$ into an air-tight loop of a known volume. Total counting 
times were $2 \mathrm{~h}$ for surface water and 40 min for groundwater. Uncertainties based on 4 replicates are less than $15 \%$ for ${ }^{222} \mathrm{Rn}$ activities below $1000 \mathrm{~Bq} \mathrm{~m}^{-3}$ and less than $5 \%$ for ${ }^{222} \mathrm{Rn}$ activities above $1000 \mathrm{~Bq} \mathrm{~m}^{-3}$. Streambed sediments were sampled at Tambo Upper on the Tambo River for ${ }^{222} \mathrm{Rn}$ ingrowth experiments. Four sediment samples of approximately $1.45 \mathrm{~kg}$ were allowed to equilibrate with $\sim 500 \mathrm{~mL}$ of ${ }^{226} \mathrm{Ra}$ free water for 8 weeks in air-tight bottles, before $150 \mathrm{~mL}$ of water was sampled for ${ }^{222} \mathrm{Rn}$ analysis using the methods outlined above.

\subsection{Mass balance calculations}

Assuming that both the concentration of ${ }^{222} \mathrm{Rn}$ in the atmosphere and the ingrowth of ${ }^{222} \mathrm{Rn}$ in river water through the decay of ${ }^{226} \mathrm{Ra}$ in suspended sediment are negligible (Cook et al., 2006; Mullinger et al., 2007), the inflow of groundwater along a reach $\left(I\right.$ in $\left.\mathrm{m}^{3} \mathrm{~m}^{-1} \mathrm{day}^{-1}\right)$ may be calculated from changes in ${ }^{222} \mathrm{Rn}$ activity in the river $c_{\mathrm{r}}\left(\mathrm{Bq} \mathrm{m}^{-3}\right)$ with distance $x$ (m) by (Cartwright et al., 2011; Cook et al., 2006)

$I=\left(Q \frac{\mathrm{d} c_{\mathrm{r}}}{\mathrm{d} x}-w E c_{\mathrm{r}}-F_{\mathrm{h}}+k d w c_{\mathrm{r}}+\lambda d w c_{\mathrm{r}}\right) /\left(c_{\mathrm{i}}-c_{r}\right)$,

where $Q$ is river discharge $\left(\mathrm{m}^{3} \mathrm{day}^{-1}\right), w$ is stream width $(\mathrm{m}), E$ is the evaporation rate $\left(\mathrm{m} \mathrm{day}^{-1}\right), F_{\mathrm{h}}$ is the flux of ${ }^{222} \mathrm{Rn}$ from the hyporheic zone $\left(\mathrm{Bq} \mathrm{m}^{-1} \mathrm{day}^{-1}\right), k$ is the gas transfer constant $\left(\right.$ day $\left.^{-1}\right), d$ is river depth $(\mathrm{m}), \lambda$ is the radon decay constant $\left(0.181\right.$ day $\left.^{-1}\right)$ and $c_{\mathrm{i}}$ is the activity of ${ }^{222} \mathrm{Rn}$ in groundwater $\left(\mathrm{Bq} \mathrm{m}^{-3}\right)$. The hyporheic zone can be defined as the part of the surface aquifer adjacent to the river that exchanges water with the river over relatively short distances (centimetres to tens of centimetres) on timescales of seconds to days (Boano et al., 2007; Kasahara and Wondzell, 2003). The flux of ${ }^{222} \mathrm{Rn}$ from the hyporheic zone can be represented by (Cook et al., 2006)

$F_{\mathrm{h}}=q_{\mathrm{h}}\left(c_{\mathrm{h}}-c_{\mathrm{r}}\right)$,

where $q_{\mathrm{h}}$ is the volumetric flux of water in and out of the hyporheic zone in $\mathrm{m}^{3} \mathrm{day}^{-1}$ (yielding a net flux of $0 \mathrm{~m}^{3}$ day $^{-1}$ to the river) and $c_{\mathrm{h}}$ is the activity of ${ }^{222} \mathrm{Rn}$ in the hyporheic zone (assuming a single well-mixed reservoir). While $c_{\mathrm{h}}$ is simple to measure in the field, calculating $q_{\mathrm{h}}$ has historically been solved by conducting in-stream tracer injections and modelling breakthrough curves (Runkel, 1998; Wagner and Harvey, 1997), which can be logistically difficult in large river systems. The flux of ${ }^{222} \mathrm{Rn}$ from the hyporheic zone can alternatively be estimated from river stretches that are not receiving groundwater input where there is little change in ${ }^{222} \mathrm{Rn}$ activity (Cartwright et al., 2011). If $\mathrm{d} c_{\mathrm{r}} / \mathrm{d} x=0$ and $I=0, F_{\mathrm{h}}$ may be estimated from Eq. (2) as

$F_{\mathrm{h}}=k d w c_{\mathrm{r}}+\lambda d w c_{\mathrm{r}}-w E c_{\mathrm{r}}$.

While the degassing of ${ }^{222} \mathrm{Rn}$ to the atmosphere is controlled by wind-driven turbulence in oceans, lakes and estuaries, it has been shown that degassing in upstream rivers is driven by river flow velocity, depth and width (Genereux and Hemond, 1992). As such, gas transfer rates $(k)$ were estimated using the O'Connor and Dobbins (1958) and Negulescu and Rojanski (1969) gas transfer models as modified by Genereux and Hemond (1992) and Mullinger et al. (2007):

$k=9.301 \times 10^{-3}\left(\frac{v^{0.5}}{d^{1.5}}\right)$

and

$k=4.87 \times 10^{-4}\left(\frac{v}{d}\right)^{0.85}$,

where $d$ is river depth (m) and $v$ is stream velocity $\left(\mathrm{mday}^{-1}\right)$ calculated from discharge, depth and width data.

A similar mass balance approach may also be used to estimate groundwater inflows from changes in the concentration of major ions, such as $\mathrm{Cl}$. For a conservative ion such as $\mathrm{Cl}$, mass balance calculations are simplified as decay, degassing and hyporheic flux terms are redundant. Thus Eq. (2) reduces to

$I=\left(Q \frac{\mathrm{dCl}_{\mathrm{r}}}{\mathrm{d} x}-w E \mathrm{Cl}_{\mathrm{r}}\right) /\left(\mathrm{Cl}_{\mathrm{i}}-\mathrm{Cl}_{\mathrm{r}}\right)$,

where $\mathrm{Cl}_{\mathrm{i}}$ and $\mathrm{Cl}_{\mathrm{r}}$ are the concentrations of $\mathrm{Cl}$ in the groundwater and river, respectively.

\section{Results}

\section{$3.1 \quad{ }^{222} \mathrm{Rn}$ activities}

Figure 3 shows the ${ }^{222} \mathrm{Rn}$ activities from all sampling campaigns on the Tambo River. These range from 52 to $604 \mathrm{~Bq} \mathrm{~m}^{-3}$ and show significant spatial and temporal variation. Average ${ }^{222} \mathrm{Rn}$ activities were highest for the Tambo River during August $2011\left(380 \pm 62 \mathrm{~Bq} \mathrm{~m}^{-3}\right)$ and lowest during April $2011\left(160 \pm 50 \mathrm{~Bq} \mathrm{~m}^{-3}\right) .{ }^{222} \mathrm{Rn}$ activities were generally higher at $28.5,16.2$ and $13.8 \mathrm{~km}$ compared to other locations with average activities of $302 \pm 51,288 \pm 51$ and $326 \pm 37 \mathrm{~Bq} \mathrm{~m}^{-3}$, respectively. ${ }^{222} \mathrm{Rn}$ activities were generally lower at 20.0 and $1.8 \mathrm{~km}$, with average ${ }^{222} \mathrm{Rn}$ activities of $184 \pm 52 \mathrm{~Bq} \mathrm{~m}^{-3}$ and $105 \pm 37 \mathrm{~Bq} \mathrm{~m}^{-3}$, respectively. ${ }^{222} \mathrm{Rn}$ activities in the Nicholson River were generally lower than those in the Tambo River, with 16 of the 27 samples yielding activities below $120 \mathrm{~Bq} \mathrm{~m}^{-3}$. During April and September $2010,{ }^{222} \mathrm{Rn}$ activities in the Nicholson River were $<100 \mathrm{~Bq} \mathrm{~m}^{-3}$ at all sites except $13.6 \mathrm{~km}$, which had activities of 370 and $734 \mathrm{~Bq} \mathrm{~m}^{-3}$, respectively (Fig. 4). In February 2011 activities were $<200 \mathrm{~Bq} \mathrm{~m}^{-3}$ for all sites except at $3.2 \mathrm{~km}$, which had an activity of $856 \mathrm{~Bq} \mathrm{~m}^{-3}$. Activities varied little during April 2011, with all activities below $120 \mathrm{~Bq} \mathrm{~m}^{-3}$. In August 2011 and March 2012, activities were $<200 \mathrm{~Bq} \mathrm{~m}^{-3}$ at all sites except the uppermost sample point $(21.2 \mathrm{~km})$, in which activities were 891 and $292 \mathrm{~Bq} \mathrm{~m}^{-3}$, respectively. 


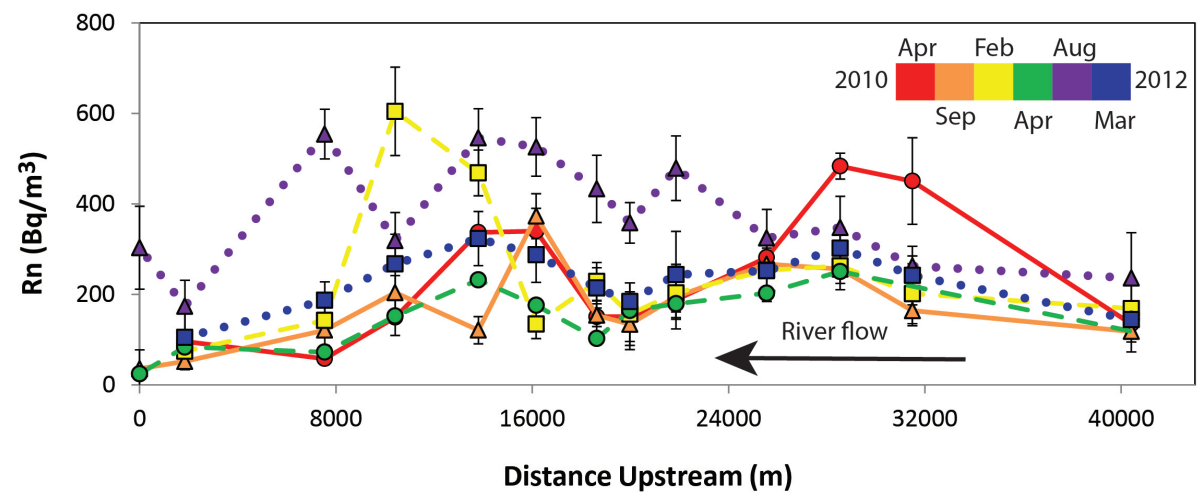

Fig. 3. Distribution of ${ }^{222} \mathrm{Rn}$ activities in water sampled from the Tambo River over the study period. Apil $2010=$ solid line with circles, September $2010=$ solid line with triangles, February $2011=$ dashed line with squares, Apil $2011=$ dashed lines with circles, August $2011=$ dotted line with triangles, Mach $2012=$ dotted line with squares.

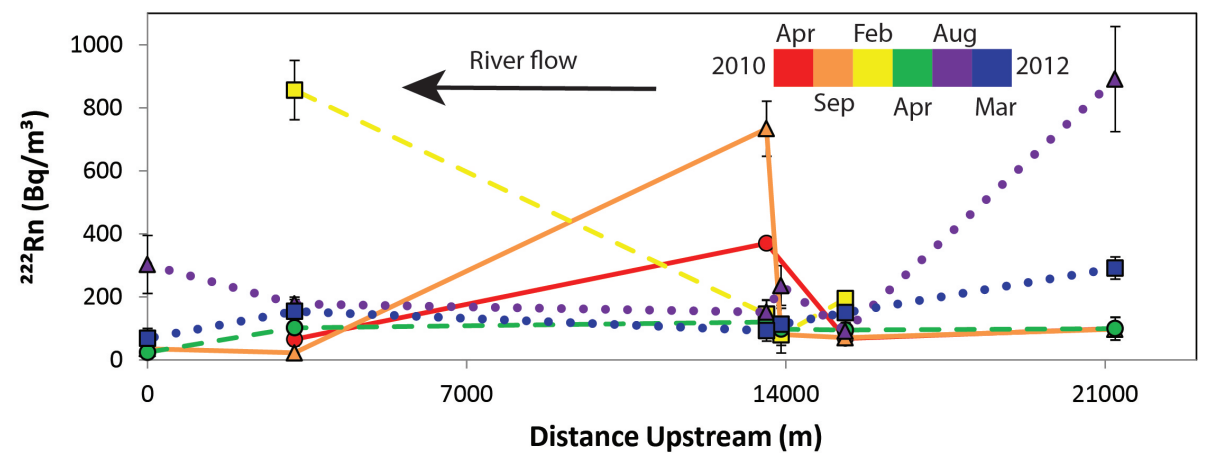

Fig. 4. Distribution of ${ }^{222} \mathrm{Rn}$ activities in water sampled from the Nicholson River over the study period. April $2010=$ solid line with circles, September $2010=$ solid line with triangles, February $2011=$ dashed line with squares, April $2011=$ dashed lines with circles, August $2011=$ dotted line with triangles, March $2012=$ dotted line with squares.

Groundwater ${ }^{222} \mathrm{Rn}$ activities at Bruthen ranged from 2380 to $9130 \mathrm{~Bq} \mathrm{~m}^{-3}$, with an average activity of $5000 \pm 2340 \mathrm{~Bq} \mathrm{~m}^{-3}$ over the study period. Average activities at this site were generally higher in February and April $2011\left(4620 \pm 2750\right.$ and $\left.5160 \pm 1970 \mathrm{~Bq} \mathrm{~m}^{-3}\right)$ and lower during August 2011 and March $2012(3100 \pm 570$ and $2150 \pm 440 \mathrm{~Bq} \mathrm{~m}^{-3}$ ). Groundwater activities at Tambo Upper were generally lower than at Bruthen, with average activities at the site ranging from $1500 \pm 170 \mathrm{~Bq} \mathrm{~m}^{-3}$ in March 2012 to $2290 \pm 2770 \mathrm{~Bq} \mathrm{~m}^{-3} \mathrm{n}$ February 2011 . Activities at this site were also highly variable, ranging from 330 to $4240 \mathrm{~Bq} \mathrm{~m}^{-3}$ over the study period. Groundwater activities at Kelly Creek were the highest of any site, with an average activity of $8740 \pm 3550 \mathrm{~Bq} \mathrm{~m}^{-3}$, ranging from $13480 \mathrm{~Bq} \mathrm{~m}^{-3}$ in August 2011 to $5220 \mathrm{~Bq} \mathrm{~m}^{-3}$ in March 2012. The activity of ${ }^{222} \mathrm{Rn}$ in water equilibrated with streambed sediments ranged from 1900 to $3740 \mathrm{~Bq} \mathrm{~m}^{-3}$, with an average activity of $2640 \pm 880 \mathrm{~Bq} \mathrm{~m}^{-3}$ (Table 1). This is within the range of the average ${ }^{222} \mathrm{Rn}$ activities of groundwater at Bruthen and Tambo Upper (2320 to $4600 \mathrm{~Bq} \mathrm{~m}^{-3}$ ).
Table 1. Activity of water equilibrated with streambed sediments in four samples.

\begin{tabular}{lccccccc}
\hline Sample & ${ }^{222} \mathrm{Rn}$ & Test 1 & Test 2 & Test 3 & Test 4 & Average & $\begin{array}{c}\text { Std. } \\
\text { deviation } \\
1 \sigma\end{array}$ \\
\hline 1 & & & & & & & 310 \\
2 & $\mathrm{~Bq} \mathrm{~m}^{-3}$ & 2540 & 2980 & 3300 & 3010 & 2960 & 590 \\
3 & $\mathrm{~Bq} \mathrm{~m}^{-3}$ & 1230 & 2230 & 2600 & 1850 & 1980 & 320 \\
4 & $\mathrm{~Bq} \mathrm{~m}^{-3}$ & 3170 & 3830 & 3970 & 3990 & 3740 & 390 \\
\hline
\end{tabular}

\subsection{River gauging and water elevation}

The parameters used to calculate net groundwater fluxes $I_{\mathrm{N}}$ using Eq. (1) are listed in Table 2. The discharge of the Tambo River at the Battens Landing station varied by up to two orders of magnitude during the study, ranging from $6.6 \times 10^{4} \mathrm{~m}^{3}$ day $^{-1}$ in April 2010 to $7.9 \times 10^{6} \mathrm{~m}^{3}$ day $^{-1}$ in August 2011. Direct rainfall to the river for the $48 \mathrm{hr}$ period leading up to and including sampling/analysis ranged from 0 to $4093 \mathrm{~m}^{3} \mathrm{day}^{-1}$. Direct evaporative losses for the same periods were on a similar order of magnitude as 
Table 2. Parameters used for calculating the net groundwater flux $(I)$ by differential flow gauging using Eq. (1).

\begin{tabular}{lrrrrrr}
\hline Parameter & $10 \mathrm{Apr}$ & $10 \mathrm{Sep}$ & $11 \mathrm{Feb}$ & $11 \mathrm{Apr}$ & $11 \mathrm{Aug}$ & \multicolumn{1}{c}{$12 \mathrm{Mar}$} \\
\hline$Q_{\mathrm{u}}\left(\mathrm{m}^{3} \mathrm{day}^{-1}\right)$ & 60473 & 305115 & 152516 & 188493 & 7328592 & 1249945 \\
$Q_{\mathrm{d}}\left(\mathrm{m}^{3} \mathrm{day}^{-1}\right)$ & 65978 & 354034 & 178316 & 201032 & 7869027 & 1393043 \\
$P\left(\mathrm{~m}^{3} \mathrm{day}^{-1}\right)$ & 238 & 0 & 4093 & 3378 & 119 & 40 \\
$E\left(\mathrm{~m}^{3} \mathrm{day}^{-1}\right)$ & 1033 & 1073 & 1974 & 636 & 636 & 1788 \\
$I_{\mathrm{N}}\left(\mathrm{m}^{3} \mathrm{day}^{-1}\right)$ & 6300 & 49992 & 23681 & 9797 & 540952 & 144846 \\
\hline
\end{tabular}

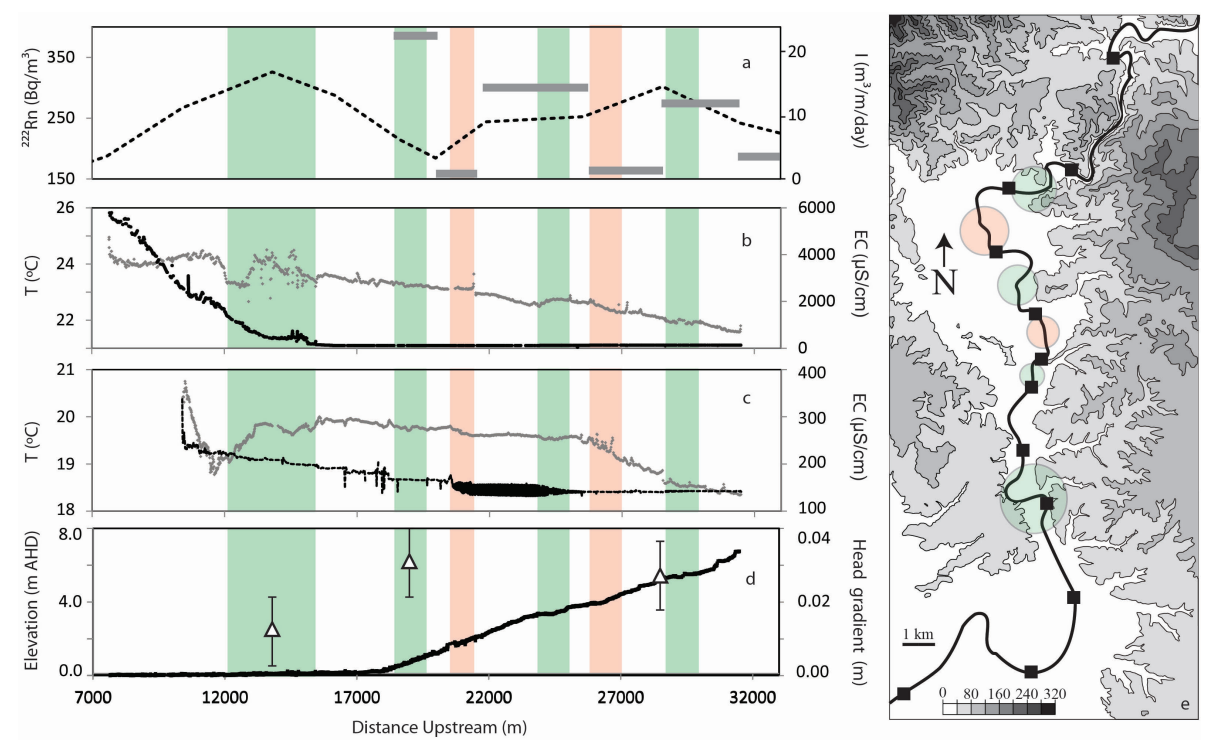

Fig. 5. Inferred zones of increased groundwater discharge (green shading) and decreased groundwater discharge (red shading) on the Tambo River as indicated by (a) average ${ }^{222} \mathrm{Rn}$ activities (dashed line) and average groundwater fluxes by ${ }^{222} \mathrm{Rn}$ mass balance (grey bars), temperature (grey dots) and EC (black dots) profiles from February 2011 (b) and March 2012 (c), average groundwater-surface water gradients (triangles) surface water elevation (black line) (d), and local topography (e).

rainfall, ranging from 636 to $1974 \mathrm{~m}^{3} \mathrm{day}^{-1}$ and averaging $1190 \mathrm{~m}^{3}$ day $^{-1}$.

River elevation during the February 2011 survey decreased from 6.66 to $-0.15 \mathrm{~m}$ between 31.5 and $18.1 \mathrm{~km}$ with a slope of $\sim 0.46 \mathrm{~m} \mathrm{~km}^{-1}$. River slope increased to $1.1 \mathrm{~m} \mathrm{~km}^{-1}$ between 30.5 and $30.0 \mathrm{~km}$ and to $0.79 \mathrm{~m} \mathrm{~km}^{-1}$ between 29.5 and $29.2 \mathrm{~km}$, but decreased to $0.2 \mathrm{~m} \mathrm{~km}^{-1}$ between 24.7 and $23.7 \mathrm{~km}$ before levelling out to $-0.01 \pm 0.06 \mathrm{~m}$ downstream of $18.1 \mathrm{~km}$. Groundwater elevations neighbouring the Tambo River were the highest in August 2011, ranging from $8.86 \mathrm{~m}$ at Bruthen to $3.63 \mathrm{~m}$ at Kelly Creek. Elevations were the lowest in April 2011, ranging from $7.51 \mathrm{~m}$ at Bruthen to $3.15 \mathrm{~m}$ at Kelly Creek. Hydraulic gradients at Bruthen were towards the Tambo River (positive) in all campaigns except August 2011. Hydraulic gradients ranged from -0.018 (August 2011) to 0.112 (March 2012), with an average gradient of $0.027 \pm 0.019$ (Fig. 5d). Hydraulic gradients at Tambo Upper were towards the river during all campaigns, ranging from 0.001 in August 2011 to 0.075 in March 2012, with an average gradient of $0.033 \pm 0.013$. The hydraulic gradient at Kelly Creek in February was 0.013.

\subsection{Temperature and EC surveys}

Results from the temperature/EC surveys on the Tambo River are illustrated in Fig. 5. The temperature of river water in February increased from $21.6^{\circ} \mathrm{C}$ at $31.5 \mathrm{~km}$ to $25.0^{\circ} \mathrm{C}$ at $7.7 \mathrm{~km}$ (Fig. 5b). Groundwater temperatures near the Tambo River at this time were $\sim 15.5^{\circ} \mathrm{C}$ at Bruthen, increasing to $\sim 16.5^{\circ} \mathrm{C}$ at Kelly Creek. Temperature increase was generally gradual in the Tambo River between 31.5 and $15.6 \mathrm{~km}\left(\sim 0.11^{\circ} \mathrm{C} \mathrm{km}^{-1}\right)$. River temperature however remained constant at $\sim 20.0^{\circ} \mathrm{C}$ between 29.9 and $28.7 \mathrm{~km}$. Temperature also remained constant at $\sim 23.2^{\circ} \mathrm{C}$ between 20.5 and $18.9 \mathrm{~km}$, and declined from 22.8 to $22.5^{\circ} \mathrm{C}$ between 24.8 and $24.0 \mathrm{~km}$. Higher rates of temperature increase occurred between 26.6 and $25.8 \mathrm{~km}\left(\sim 0.5^{\circ} \mathrm{C} \mathrm{km}^{-1}\right)$ and between 21.5 and $21.4 \mathrm{~km}\left(\sim 7^{\circ} \mathrm{C} \mathrm{km}^{-1}\right)$. Downstream of $15.6 \mathrm{~km}$ the river became estuarine and temperatures more variable, ranging from 23 to $25^{\circ} \mathrm{C}$ with a drop in temperature of $>1.0^{\circ} \mathrm{C}$ between 13.2 and $11.8 \mathrm{~km}$. River EC values in February ranged from 112 to $9270 \mu \mathrm{S} \mathrm{cm}^{-1}$, with a sharp increase from 120 to $645 \mu \mathrm{S} \mathrm{cm}^{-1}$ between 


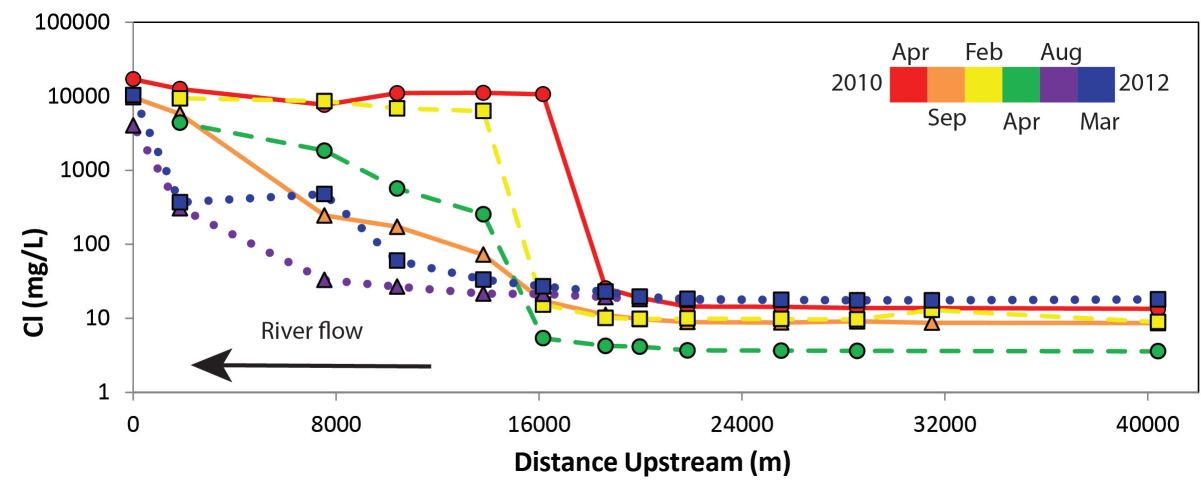

Fig. 6. Distribution of $\mathrm{Cl}$ concentrations in water sampled from the Tambo River over the study period. April $2010=$ solid line with circles, September $2010=$ solid line with triangles, February $2011=$ dashed line with squares, April $2011=$ dashed lines with circles, August $2011=$ dotted line with triangles, March $2012=$ dotted line with squares.

16 and $15 \mathrm{~km}$, indicating the mixing of fresh water with estuarine water. ECs changed very little between 31.5 and $15 \mathrm{~km}$ (from 114 to $150 \mu \mathrm{S} \mathrm{cm}^{-1}$ ) and increased variably to $>9270 \mu \mathrm{S} \mathrm{cm}^{-1}$ downstream of $15 \mathrm{~km}$. Groundwater EC during February 2011 ranged from 145 to $260 \mu \mathrm{S} \mathrm{cm}^{-1}$ at Bruthen, from 2200 to $2400 \mu \mathrm{S} \mathrm{cm}^{-1}$ at Tambo Upper and was $7080 \mu \mathrm{S} \mathrm{cm}^{-1}$ at Kelly Creek.

Surface and groundwater temperatures were less variable in March 2012, with groundwater increasing from $\sim 15.3^{\circ} \mathrm{C}$ at Bruthen to $\sim 15.5^{\circ} \mathrm{C}$ at Kelly Creek and river water ranging from 18.4 to $20.1{ }^{\circ} \mathrm{C}$. River temperature remained at $\sim 18.5^{\circ} \mathrm{C}$ between 30.1 and $29.2 \mathrm{~km}$ (Fig. $5 \mathrm{c}$ ) before increasing irregularly to $19.6^{\circ} \mathrm{C}$ between 29.2 and $25.5 \mathrm{~km}$. Temperatures then declined to $19.4^{\circ} \mathrm{C}$ between 25.5 and $24.3 \mathrm{~km}$ before stabilising at $19.5 \pm 0.1^{\circ} \mathrm{C}$ between 24.3 and $21.1 \mathrm{~km}$. River temperature then increased to $19.8^{\circ} \mathrm{C}$ between 21.1 and $20.3 \mathrm{~km}$ before stabilising at $19.8 \pm 0.1^{\circ} \mathrm{C}$ between 20.3 and $15.8 \mathrm{~km}$. Downstream of $15.8 \mathrm{~km}$ temperature increased variably as the river became estuarine, with an initial drop in temperature from 19.8 to $18.8^{\circ} \mathrm{C}$ between 13.7 and $11.7 \mathrm{~km}$. River EC during March 2012 ranged from 141 to $195 \mu \mathrm{S} \mathrm{cm}^{-1}$ between 40.4 and $20.1 \mathrm{~km}$ before increasing variably to $338 \mu \mathrm{S} \mathrm{cm}^{-1}$ downstream of $16 \mathrm{~km}$. Groundwater EC in March 2012 ranged from 140 to $290 \mu \mathrm{S} \mathrm{cm}^{-1}$ at Bruthen, from 1650 to $1850 \mu \mathrm{S} \mathrm{cm}^{-1}$ at Tambo Upper and was $3410 \mu \mathrm{S} \mathrm{cm}^{-1}$ at Kelly Creek.

\subsection{Chloride concentrations}

$\mathrm{Cl}$ concentrations in the Tambo River follow a similar trend to EC values from EC/temperature surveys (Fig. 6), with lower $\mathrm{Cl}$ concentrations increasing gradually in the upstream reaches (between 40.4 and $20.0 \mathrm{~km}$ ) and more significant increases between $20.0 \mathrm{~km}$ and Lake King as the river becomes estuarine. Upstream $\mathrm{Cl}$ concentrations were the lowest in April 2011 and the highest in April 2010, with concentration ranges of 3.58 to $4.14 \mathrm{mg} \mathrm{L}^{-1}$ and 13.43 to $18.94 \mathrm{mg} \mathrm{L}^{-1}$, respectively. The interface between fresh upstream water and saline lake water varied considerably in the Tambo River. Under low-flow conditions in April 2010, $\mathrm{Cl}$ concentrations increased from 25.5 to $10700 \mathrm{mg} \mathrm{L}^{-1}$ between 18.6 and $16.2 \mathrm{~km}$, but under high-flow conditions in August 2011, Cl concentrations were $33.0 \mathrm{mg} \mathrm{L}^{-1}$ at $7.5 \mathrm{~km}$ and $4030 \mathrm{mg} \mathrm{L}^{-1}$ at Lake King. Similar trends were observed on the Nicholson River, with $\mathrm{Cl}$ concentrations increasing from 15.1 to $4950 \mathrm{mg} \mathrm{L}^{-1}$ between 21.2 and $15.3 \mathrm{~km}$ in April 2010, and from 53.2 to $4030 \mathrm{mg} \mathrm{L}^{-1}$ between $3.2 \mathrm{~km}$ and Lake King in August 2011 (Fig. 7). Upstream Cl concentrations in the Nicholson River were also lower in April 2011 and higher during April 2010, with minimum $\mathrm{Cl}$ concentrations of 6.43 and $15.14 \mathrm{mg} \mathrm{L}^{-1}$, respectively.

$\mathrm{Cl}$ concentrations in groundwater at Bruthen were the highest during March 2012, with a range of 17.8 to $23.4 \mathrm{mg} \mathrm{L}^{-1}$. Average $\mathrm{Cl}$ concentrations at this location were the lowest during April 2011, with a range of 6.75 to $10.3 \mathrm{mg} \mathrm{L}^{-1}$. Concentrations at Tambo Upper were significantly higher than Bruthen, with concentrations ranging between 385 and $599 \mathrm{mg} \mathrm{L}^{-1}$ over the study period. Concentrations at Tambo Upper were generally higher in February $2011\left(563 \pm 11.7 \mathrm{mg} \mathrm{L}^{-1}\right)$ and lower in March 2012 $\left(464 \pm 112 \mathrm{mg} \mathrm{L}^{-1}\right)$. Concentrations at Kelly Creek were higher than at Tambo Upper, ranging from $474 \mathrm{mg} \mathrm{L}^{-1}$ in April 2011 to $598 \mathrm{mg} \mathrm{L}^{-1}$ in March 2012.

\subsection{Groundwater fluxes}

\subsection{1 $\quad{ }^{222}$ Rn mass balance}

Groundwater fluxes were calculated using Eq. (2). River discharge $(Q)$ for the Tambo River was based on interpolation between discharge at the Ramrod Creek $(40.4 \mathrm{~km})$ and Battens Landing $(20 \mathrm{~km})$ flow gauging stations, while $Q$ for the Nicholson River uses the discharge at the Sarsfield gauging station at $15.3 \mathrm{~km}$. As flow gauging did not occur in the river estuaries where river discharge will vary tidally, groundwater fluxes were not calculated where EC data indicate estuarine 


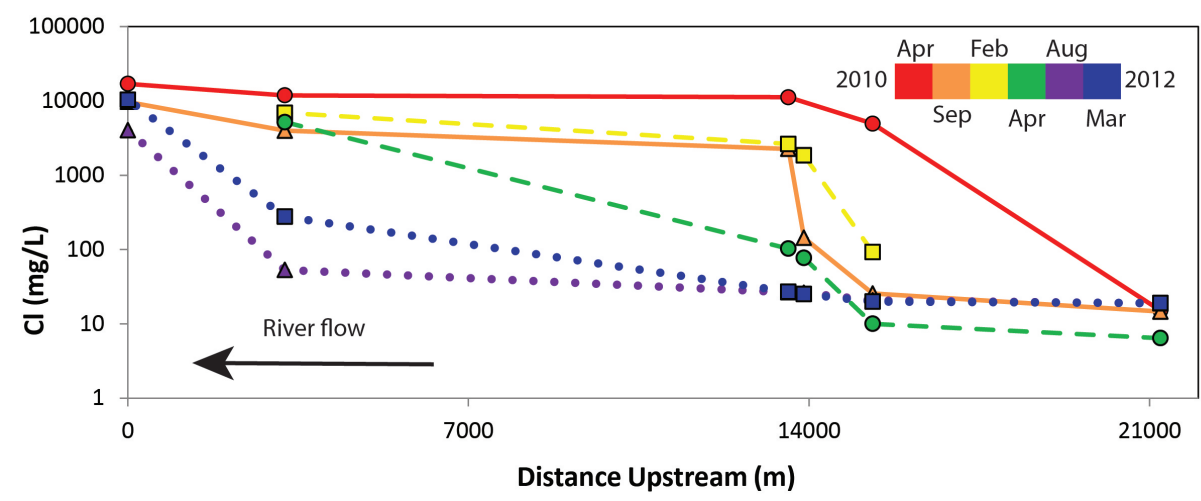

Fig. 7. Distribution of $\mathrm{Cl}$ concentrations in water sampled from the Nicholson River over the study period. April $2010=$ solid line with circles, September $2010=$ solid line with triangles, February $2011=$ dashed line with squares, April $2011=$ dashed lines with circles, August $2011=$ dotted line with triangles, March $2012=$ dotted line with squares.

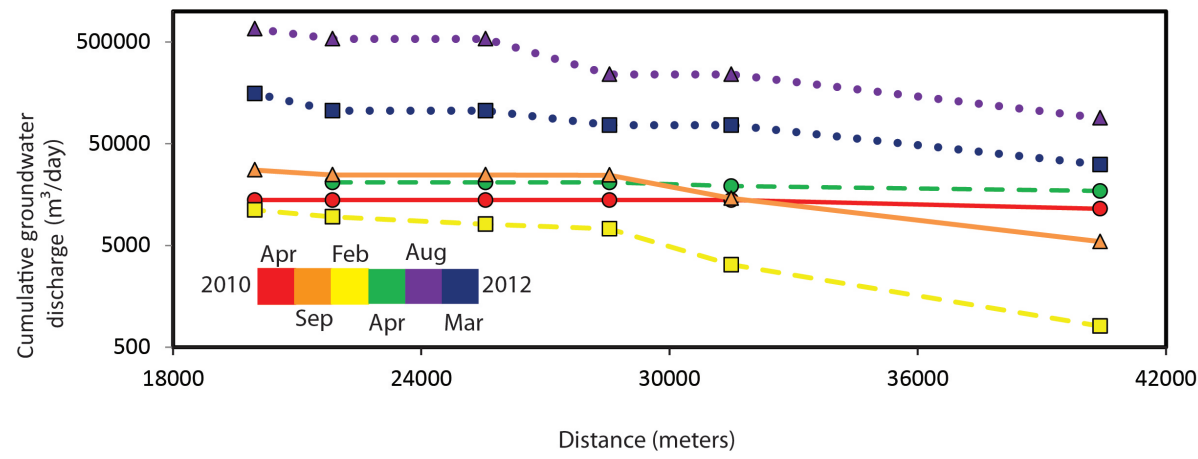

Fig. 8. Cumulative groundwater discharge to the Tambo River from ${ }^{222} \mathrm{Rn}$ mass balance. April $2010=$ solid line with circles, September $2010=$ solid line with triangles, February $2011=$ dashed line with squares, April $2011=$ dashed lines with circles, August $2011=$ dotted line with triangles, March $2012=$ dotted line with squares.

conditions. Calculations are based on the average ${ }^{222} \mathrm{Rn}$ activity of groundwater $\left(C_{\mathrm{i}}\right)$ measured in each sampling round at Bruthen and Tambo Upper (total $=5$ bores). Groundwater from these bores is located in the upstream reaches for which groundwater fluxes have been calculated and has ${ }^{222} \mathrm{Rn}$ activities that are within $2000 \mathrm{~Bq} \mathrm{~m}^{-3}$ of the average of the sediment ingrowth experiments (Table 1).

Groundwater fluxes for a given reach are calculated using the average depth, width and gas transfer velocities for that reach. The flux of ${ }^{222} \mathrm{Rn}$ from the hyporheic zone $\left(F_{\mathrm{h}}\right)$ of the Tambo River is estimated using Eq. (4). Groundwater fluxes $(I)$ of $0 \mathrm{~m}^{3} \mathrm{~m}^{-1} \mathrm{day}^{-1}$ were calculated by $\mathrm{Cl}$ and ${ }^{222} \mathrm{Rn}$ mass balance between 21.9 and $20.0 \mathrm{~km}$ in February 2011 (Figs. 8 and 9). At that time there is little change in ${ }^{222} \mathrm{Rn}$ activities along this stretch of river (i.e. $\mathrm{d} c_{\mathrm{r}} / \mathrm{d} x \sim 0$ ). Using $k=1.16$ day $^{-1}, \quad E=5 \times 10^{-3} \mathrm{~m} \mathrm{day}^{-1} \quad$ (Bureau of Meteorology, 2012) and $C_{\mathrm{r}}=150 \mathrm{~Bq} \mathrm{~m}^{-3}$ yields $F_{\mathrm{h}}=5440 \mathrm{~Bq} \mathrm{~m}^{-1} \mathrm{day}^{-1}$. A similar calculation was made for the Nicholson River for April 2011. $\mathrm{Cl}$ and ${ }^{222} \mathrm{Rn}$ mass balance for the stretch between 13.6 and $3.2 \mathrm{~km}$ yielded $I=0 \mathrm{~m}^{3} \mathrm{~m}^{-1}$ day $^{-1}$, and again there is little change in ${ }^{222} \mathrm{Rn}$ activities. For $k=0.1 \mathrm{~m}$ day $^{-1}, E=5 \times 10^{-3} \mathrm{~m}_{\text {day }^{-1}}$ and $C_{\mathrm{r}}=102 \mathrm{~Bq} \mathrm{~m}^{-3}, F_{\mathrm{h}}=7610 \mathrm{~Bq} \mathrm{~m}^{-1} \mathrm{day}^{-1}$. The river morphology and streambed sediment of these sections are representative of the Tambo and Nicholson rivers and likely to accurately represent $F_{\mathrm{h}}$ to the rivers. It is possible however that $F_{\mathrm{h}}$ will vary over time and location as a function of river slope and $I$. The uncertainties associated with $F_{\mathrm{h}}$ are discussed further in Sect. 4.2.

Total groundwater discharge between 40.4 and $18.6 \mathrm{~km}$ on the Tambo River ranged from 9660 to $24700 \mathrm{~m}^{3}$ day $^{-1}$ between April 2010 and April 2011 (Fig. 8). This reflects between 21.4 and $10.5 \%$ of river discharge under low-flow conditions (April 2010 and 2011, respectively), and between 6.83 and $7.44 \%$ of river discharge under intermediate-flow conditions (September 2010 and February 2011, respectively). Under higher-flow conditions during August 2011 and March 2012, groundwater discharge ranged from 535000 to $105000 \mathrm{~m}^{3}$ day $^{-1}$ (Fig. 8), representing 12.7 and $8.2 \%$ of river discharge, respectively. Groundwater fluxes were generally higher, between 31.5 and $28.5 \mathrm{~km}$, in comparison to other reaches. Between April 2010 and April 2011 fluxes to this section ranged from 0 to $3.3 \mathrm{~m}^{3} \mathrm{~m}^{-1}$ day $^{-1}$, increasing to 50.1 and 


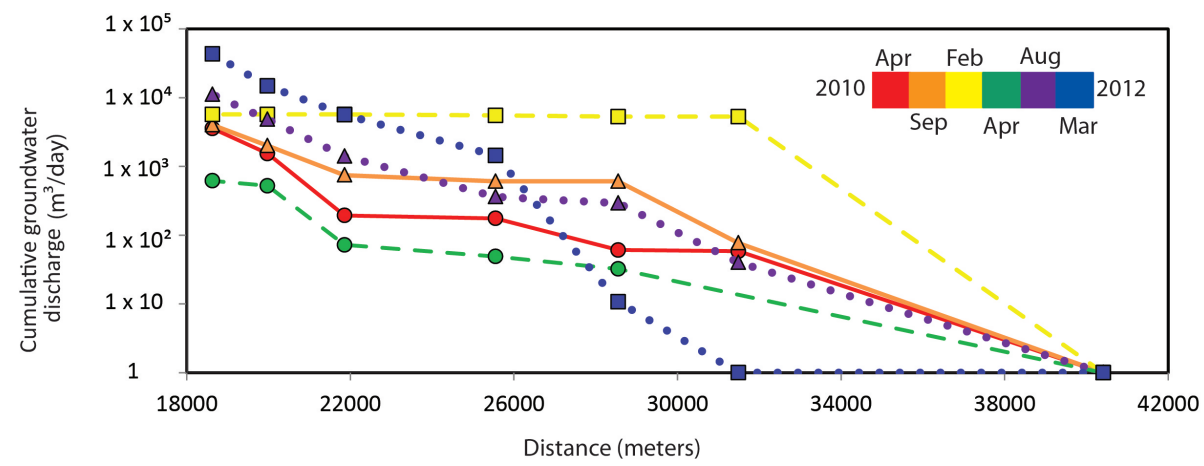

Fig. 9. Cumulative groundwater discharge to the Tambo River from $\mathrm{Cl}$ mass balance. April $2010=$ solid line with circles, September $2010=$ solid line with triangles, February $2011=$ dashed line with squares, April $2011=$ dashed lines with circles, August $2011=$ dotted line with triangles, March $2012=$ dotted line with squares.

$15.3 \mathrm{~m}^{3} \mathrm{~m}^{-1} \mathrm{day}^{-1}$ during August 2011 and March 2012, respectively. Groundwater fluxes were generally lower between 21.9 and $20.0 \mathrm{~km}$, with fluxes of $0 \mathrm{~m}^{3} \mathrm{~m}^{-1}$ day $^{-1}$ during all periods except February $2011\left(0.78 \mathrm{~m}^{3} \mathrm{~m}^{-1}\right.$ day $\left.^{-1}\right)$.

Groundwater fluxes were not calculated for the Nicholson River during April 2010 and February 2011 due to tidal forcing in the upper reaches. Total groundwater discharge to the Nicholson River was lower than the Tambo River, ranging from $88.4 \mathrm{~m}^{3}$ day $^{-1}$ in April 2011 to $32900 \mathrm{~m}^{3}$ day $^{-1}$ in August 2012. Similar to the Tambo River, groundwater reflected a higher proportion of river discharge under low-flow conditions in September 2010 (18.9\%), a lower proportion of river discharge under intermediate-flow conditions in April 2011 $(<1 \%)$ and an intermediate proportion of river discharge under high-flow conditions in August 2011 and March 2012 (10.9 and $14.9 \%$, respectively).

\subsubsection{Cl mass balance}

Groundwater fluxes were estimated from $\mathrm{Cl}$ concentrations using Eq. (1). Groundwater fluxes were only calculated for the upstream reaches in which estuarine water did not impact $\mathrm{Cl}$ concentrations. $\mathrm{Cl}$ mass balance calculations for the Tambo River are based on the average $\mathrm{Cl}$ concentrations of groundwater from Bruthen and Tambo Upper, which ranged from 228 to $253 \mathrm{mg} \mathrm{L}^{-1}$. For the Nicholson River, $\mathrm{Cl}$ mass balance was conducted between 21.2 and $13.5 \mathrm{~km}$ for all periods except August 2011. Groundwater sampling near the Nicholson River was not possible; however, the regional groundwater near the Nicholson River has similar TDS concentrations to groundwater at Tambo Upper (Department of Environment and Primary Industries, 2013). Furthermore Cl is the dominant anion in groundwater in this region and its concentration varies regularly with TDS (Victorian Water Resources Data Warehouse, 2012). Thus, the $\mathrm{Cl}$ concentrations from Tambo Upper have been used to calculate the fluxes along the Nicholson River.
Groundwater fluxes to the Tambo River from $\mathrm{Cl}$ mass balance range from 0 to $4.85 \mathrm{~m}^{3} \mathrm{~m}^{-1} \mathrm{day}^{-1}$. Fluxes were generally higher, between 21.9 and $20.0 \mathrm{~km}$, with an average flux of $1.17 \pm 1.82 \mathrm{~m}^{3} \mathrm{~m}^{-1}$ day $^{-1}$. Total groundwater discharge was the highest in March $2012\left(14800 \mathrm{~m}^{3} \mathrm{day}^{-1}\right)$ and the lowest in April $2011\left(522 \mathrm{~m}^{3} \mathrm{day}^{-1}\right)$ (Fig. 9). Groundwater constituted the highest proportion of river discharge in April 2010 (2.4\%) and the lowest under intermediateflow conditions in September $2010(0.61 \%)$. Groundwater discharge to the Nicholson River was higher during August $2011\left(38300 \mathrm{~m}^{3} \mathrm{day}^{-1}\right)$ and September 2011 $\left(20900 \mathrm{~m}^{3} \mathrm{day}^{-1}\right)$, and lower during September 2010 (4810 $\mathrm{m}^{3}$ day $\left.^{-1}\right)$ and March $2012\left(3960 \mathrm{~m}^{3} \mathrm{day}^{-1}\right)$. Groundwater discharge represented the highest proportion of river flow under low-flow conditions during September 2010 at $29.4 \%$, compared to high-flow conditions in August 2011 and March 2012 in which groundwater constituted less than $7 \%$ of total river discharge.

\section{Discussion}

This section focusses on combining chemical and physical methods in order to characterise the distribution of gaining and losing reaches along the Tambo and Nicholson rivers. The impact of changing meteorological and hydrological conditions as drivers of groundwater fluxes is also investigated. Finally the discrepancies, strengths and weaknesses of different tracer methods are discussed.

\subsection{Spatial variability of groundwater discharge to the Tambo River}

As groundwater temperatures near the Tambo River were lower than river temperatures during the temperature surveys, decreases in river temperature are likely to indicate increased groundwater discharge, while increased river temperature is likely to indicate reduced groundwater discharge (e.g. Becker et al., 2004). Temperature along the Tambo 
River in both surveys increased steadily between 31.5 and $27.0 \mathrm{~km}$ except for a zone at $\sim 29 \mathrm{~km}$ where water temperature did not increase (Fig. 5), suggesting increased groundwater discharge. Average ${ }^{222} \mathrm{Rn}$ activities at $28.5 \mathrm{~km}$ are the second highest $\left(302 \pm 100 \mathrm{~Bq} \mathrm{~m}^{-3}\right)$ of any location on the Tambo River, yielding an average groundwater flux of $12.1 \mathrm{~m}^{3} \mathrm{~m}^{-1} \mathrm{day}^{-1}$. Furthermore, groundwater-surface water gradients nearby at Bruthen were towards the river $\left(6.1 \times 10^{-3}\right.$ to 0.112$)$ during all periods except August 2011, supporting the gaining nature of this stretch. River elevation through this stretch is 5 to $10 \mathrm{~m}$, while land areas within $200 \mathrm{~m}$ of the river are over $80 \mathrm{~m}$ in elevation (Fig. 5e). Such areas of increased topography will likely result in steep hydraulic gradients towards the river (Sophocleous, 2002) and may account for the higher groundwater fluxes.

A decrease in groundwater discharge between 27.0 and $25.5 \mathrm{~km}$ is indicated by a general decline in ${ }^{222} \mathrm{Rn}$ activities (Fig. 3) and an average groundwater flux of $0.89 \mathrm{~m}^{3} \mathrm{~m}^{-1}$ day $^{-1}$ (Fig. 5a). This is supported by an increase in temperature from 22.3 to $22.7^{\circ} \mathrm{C}$ between 26.8 and $25.8 \mathrm{~km}$ in February 2011, and from 19.1 to $19.6^{\circ} \mathrm{C}$ between 26.8 and $25.4 \mathrm{~km}$ in March 2012. This stretch of river flows through extensive floodplains that extend for $>2 \mathrm{~km}$ from the river (Fig. 5e). Given the subdued topography, it is likely that groundwater head gradients are lower, which will reduce groundwater influxes. A similar trend is observed between $\sim 21$ and $\sim 19 \mathrm{~km}$, where river temperatures increased from 22.9 to $23.6^{\circ} \mathrm{C}$ in February 2011, and from 19.5 to $19.8^{\circ} \mathrm{C}$ in March 2012 , suggesting reduced groundwater discharge (Fig. $5 \mathrm{~b}$ and c). This is again supported by ${ }^{222} \mathrm{Rn}$ mass balance, which gives an average groundwater flux between 21.9 and $20.2 \mathrm{~km}$ of $0.13 \mathrm{~m}^{3} \mathrm{~m}^{-1} \mathrm{day}^{-1}$. This is also an area of low topographic variation, with likely lower head gradients (Fig. 5e).

In contrast to these sections, increased topography near the Tambo River at $\sim 25 \mathrm{~km}$ correlates with decreased river temperature both in February $2011\left(0.3^{\circ} \mathrm{C}\right)$ and March $2012\left(0.2^{\circ} \mathrm{C}\right)$, suggesting increased groundwater discharge. The average groundwater flux from ${ }^{222} \mathrm{Rn}$ mass balance between 25.5 and $21.5 \mathrm{~km}$ is also relatively high at $14.8 \mathrm{~m}^{3} \mathrm{~m}^{-1} \mathrm{day}^{-1}$. Similarly, the river section between $\sim 20$ and $19 \mathrm{~km}$ is characterised by relatively stable river temperatures and an average groundwater flux of $23.5 \mathrm{~m}^{3} \mathrm{~m}^{-1}$ day $^{-1}$ (between 20 and $18.6 \mathrm{~km}$ ). These observations support local topographic variation as a driver of groundwater discharge, with reduced groundwater discharge in regions of wider floodplains and increased groundwater discharge in areas of greater topographic variation (Fig. 5e).

Between $\sim 16$ and $6.5 \mathrm{~km}$, EC values increased to $>23000 \mu \mathrm{S} \mathrm{cm}^{-1}$ in February 2011 and $>300 \mu \mathrm{S} \mathrm{cm}^{-1}$ in March 2012, indicating the transition into an estuarine setting. In this zone, mixing with warmer lake water (25 to $30^{\circ} \mathrm{C}$; Arnott and McKinnon, 1985) is expected to cause an increase in river temperature; however river temperature declines between 13.5 and $11.5 \mathrm{~km}$, suggesting a zone of increased groundwater discharge. Nevertheless, mixing between lake water and river water through the estuarine fringe is not always systematic (e.g. MacKay and Schumann, 1990; Nunes Vaz et al., 1989; Stacey et al., 2008), and the decline in river temperature may be an artefact of measuring different water types as they mix variably through the estuarine fringe. While river discharge is not constrained through this reach preventing mass balance calculations, the average ${ }^{222} \mathrm{Rn}$ activities through this zone are the highest of any location on the Tambo River, supporting an increase in groundwater discharge. At $13.8 \mathrm{~km}$ the Tambo River is immediately adjacent to a cliff $>40 \mathrm{~m}$ in elevation. This may again facilitate high groundwater gradients toward the river resulting in higher groundwater inputs. While ${ }^{222} \mathrm{Rn}$ activities at $13.8 \mathrm{~km}$ were the highest of any sample location on the Tambo River, they were also highly variable (between 135 and $526 \mathrm{~Bq} \mathrm{~m}^{-3}$ ). This variability may reflect the transient nature of the interface between river water and lake water as they mix under tidally driven flow conditions. Furthermore, changing river flow in estuaries over tidal cycles may affect the balance of ${ }^{222} \mathrm{Rn}$ at the estuarine fringe (Santos et al., 2010). Constraining such balances requires further work and is beyond the scope of this paper. While the tidal nature of the lower river sections prevents mass balance calculations, a decline in ${ }^{222} \mathrm{Rn}$ activities through these reaches suggests reduced groundwater fluxes in the lower estuaries. Lower topographic variation through these sections (Fig. 5e) will again provide lower potential for the formation of high groundwater gradients. This is consistent with topographic variation as a driver of groundwater discharge to the Tambo River as asserted above.

\subsection{Uncertainty analysis}

The impact of uncertainties in $k$ on groundwater discharge estimates using ${ }^{222} \mathrm{Rn}$ mass balance calculations was investigated by comparing alternate $k$ values from Eqs. (5) and (6). The Negulescu and Rojanski model generally yields higher $k$ values (and hence results in higher calculated groundwater fluxes) than the O'Connor and Dobbins (1958) model, although this is reversed at low velocities and shallow depths (Fig. 10). This is demonstrated by the cumulative groundwater discharge estimates to the Tambo River, which were higher using Eq. (5) under low-flow conditions during April 2010 and February 2011, but lower during higher-flow conditions from other sampling periods. Systematic trends in $k$ values under changing flow conditions are less apparent on the Nicholson River, as river velocity is less variable and changes in river width and depth downstream have a greater impact on the the $k$ values. The difference in the cumulative groundwater discharge to the Nicholson River calculated using Eqs. (5) and (6) ranged from 3.1 to $44 \%$ with an average difference of $20 \pm 17 \%$. For the Tambo River these differences ranged from 2.5 to $48 \%$ with an average difference of $30 \pm 16 \%$. The variability in $\mathrm{k}$ is recognised as a source of 


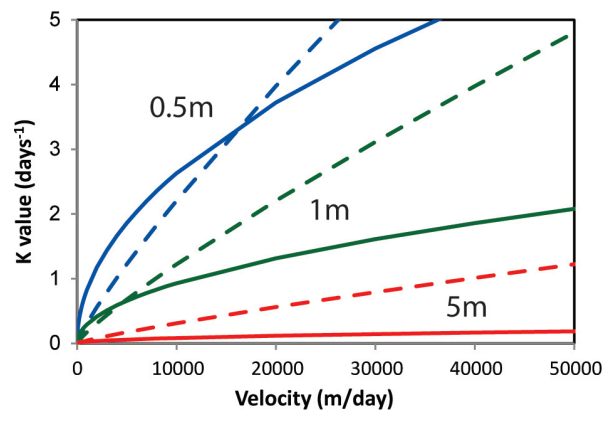

Fig. 10. $K$ values from O'Connor and Dobbins (1958) (solid lines) and Negulescu and Rohanski (1969) (dashed lines) models at $0.5 \mathrm{~m}$ (blue), $1 \mathrm{~m}$ (green) and $5 \mathrm{~m}$ depth (red) with increasing river velocities.

error in ${ }^{222} \mathrm{Rn}$ mass balance calculations; however changes to $k$ have little impact on the distribution of gaining reaches or seasonal trends in groundwater discharge identified by ${ }^{222} \mathrm{Rn}$ mass balance (Fig. 11).

For both the Tambo and Nicholson rivers, $F_{\mathrm{h}}$ estimates were made when $\mathrm{d} c / \mathrm{d} x$ was 0 (within $1 \mathrm{SD}$ of the equipment precision). As the activity of ${ }^{222} \mathrm{Rn}$ in the Tambo and Nicholson rivers is relatively low, failure to account for $F_{\mathrm{h}}$ will result in overestimations during groundwater flux calculations. On average, failure to account for $F_{\mathrm{h}}$ on the Tambo River resulted in a $104 \%$ increase in groundwater discharge. Excluding April 2011, failure to account for $F_{\mathrm{h}}$ on the Nicholson River results in an average increase in the estimated groundwater discharge by $45 \%$. As ${ }^{222} \mathrm{Rn}$ activities in the Nicholson are particularly low $\left(<120 \mathrm{~Bq} \mathrm{~m}^{-3}\right)$ at all locations during April 2011, failure to account for $F_{\mathrm{h}}$ at this time results in nearly a $630 \%$ increase in the groundwater discharge estimate. This illustrates the need to account for $F_{\mathrm{h}}$ in streams with lower ${ }^{222} \mathrm{Rn}$ activities where the $\mathrm{dc}_{r} / \mathrm{dx}$ term in Eq. (2) is small (cf. Cook et al., 2006).

The variability of $C_{\mathrm{i}}$ represents the greatest source of uncertainty in ${ }^{222} \mathrm{Rn}$ mass balance calculations as $C_{\mathrm{i}}$ values varied by up to 3 orders of magnitude at different locations. As $C_{\mathrm{i}} \gg C_{\mathrm{r}}$ during all sampling periods, a $50 \%$ change in $C_{\mathrm{i}}$ will result in an approximately $50 \%$ change in $I$. The sensitivity of the model to $C_{\mathrm{i}}$ is demonstrated by calculating $I$ at one standard deviation from the average $C_{\mathrm{i}}$ values used during mass balance calculations. For example, during February 2011 when $C_{\mathrm{i}}$ was the most varied $\left(4600 \pm 2750 \mathrm{~Bq} \mathrm{~m}^{-3}\right)$, groundwater discharge to the Tambo River will range from 5860 to $25800 \mathrm{~m}^{3}$ day $^{-1}$ based on $C_{\mathrm{i}}$ values one standard deviation from the mean. This demonstrates the need to accurately assign groundwater end member values. The variability of ${ }^{222} \mathrm{Rn}$ activity in groundwater remains a source of uncertainty when conducting groundwater studies, and further research in characterising such variability both spatially and temporally would be useful to subsequent studies.
The sensitivity of the $\mathrm{Cl}$ mass balance model to $\mathrm{Cl}_{\mathrm{i}}$ on the Tambo River was tested by assuming the $\mathrm{Cl}_{\mathrm{i}}$ end member was a mixture between groundwater from Bruthen and Tambo Upper, and then varying the weighting between each location. Using Tambo Upper concentrations as the end member reduced groundwater discharge estimates for the stretch by between 39 and $40 \%$ during individual sampling periods. Estimates using the Bruthen concentrations as the end member increased estimates by 2 to 4 orders of magnitude during September 2010, February 2011, April 2011 and March 2012 and reduced estimates to 0 during April 2010 and August 2011 periods. $\mathrm{Cl}_{\mathrm{i}}$ again represents the greatest source of uncertainty in mass balance calculations given that values vary by up to 3 orders of magnitude between Bruthen and Tambo Upper. Furthermore, $C_{\mathrm{i}}$ is generally similar to $C_{\mathrm{r}}$ in upstream reaches, making $\mathrm{Cl}$ mass balance calculations very sensitive to variations in $C_{\mathrm{i}}$ as opposed to ${ }^{222} \mathrm{Rn}$ mass balance calculations where $C_{\mathrm{i}} \gg C_{\mathrm{r}}$. This again highlights the need for accurate characterisation of groundwater end members.

\subsection{Method comparison}

While similar temporal trends in groundwater discharge to the Tambo River (i.e. increased groundwater discharge under high-flow conditions) were identified by differential flow gauging, $\mathrm{Cl}$ mass balance and ${ }^{222} \mathrm{Rn}$ mass balance, estimates from $\mathrm{Cl}$ mass balance were generally 1 to 2 orders of magnitude lower than those from ${ }^{222} \mathrm{Rn}$ mass balance or differential flow gauging (Fig. 12). It is likely that some discrepancies between the tracer methods result from uncertainties in groundwater end member characterisation, and the sensitivity of the mass balance models to this parameter. It has been shown that interaction between groundwater and surface water near rivers is likely to increase the variability of groundwater chemistry near rivers, making accurate characterisation of the groundwater end member difficult (Lambs, 2004; McCallum et al., 2010). For example, infiltration of river water into the banks at high river discharges may result in near-river groundwater having lower $\mathrm{Cl}$ concentrations than the regional groundwater. This would result in the fluxes from $\mathrm{Cl}$ mass balance being too low (McCallum et al., 2012). Bank infiltration will vary as a function of river morphology, aquifer characteristics and changing flow conditions (Chen and Chen, 2003; Chen et al., 2006; Lambs, 2004; McCallum et al., 2010; Woessner, 2000) and is difficult to characterise accurately. While this study sampled near-river groundwater, it is possible that the near-river groundwater along the Tambo River has variable $\mathrm{Cl}$ concentrations, resulting in a level of uncertainty in the characterisation of groundwater end members.

Discrepancies between the $\mathrm{Cl}$ and ${ }^{222} \mathrm{Rn}$ mass balances may also reflect the discharge of relatively young groundwater that has been stored for a period of weeks, either as recently infiltrated rainfall, bank return flow or parafluvial flow 

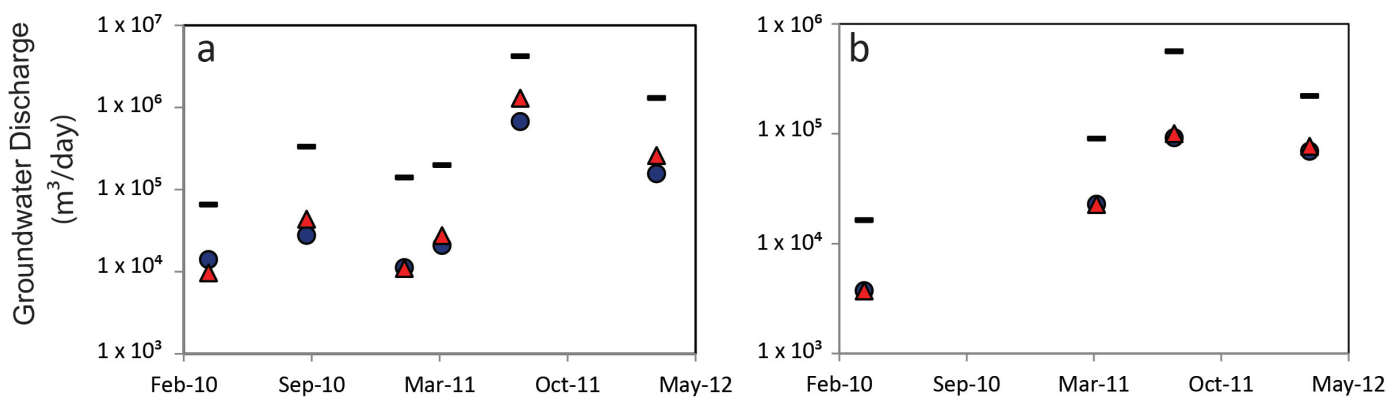

Fig. 11. Temporal variations in river discharge (black lines) and groundwater discharge to the Tambo River (a) and Nicholson River (b) given by ${ }^{222} \mathrm{Rn}$ mass balance using O'Connor and Dobbins (1958) (blue circles) and Negulescu and Rojanski (1969) (red triangles) models of gas transfer.
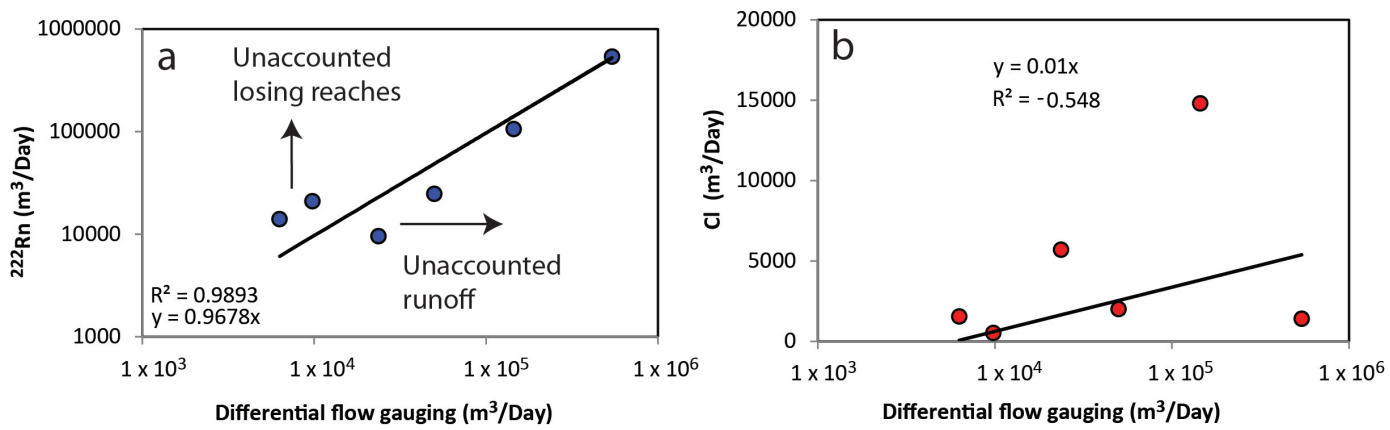

Fig. 12. Groundwater discharge to the Tambo River by differential flow gauging ( $x$ axis) versus groundwater discharge given by ${ }^{222}$ Rn mass balance (a) and $\mathrm{Cl}$ mass balance (b).

(McCallum et al., 2010; Woessner, 2000). Chemically, such groundwater would have low $\mathrm{Cl}$ concentrations but elevated ${ }^{222} \mathrm{Rn}$ activities through ingrowth (Cartwright et al., 2011). Cook (2012) makes the point that variations in groundwater $\mathrm{Cl}$ concentrations will be greater than ${ }^{222} \mathrm{Rn}$ activities as a function of such processes. Under these conditions, groundwater estimates from ${ }^{222} \mathrm{Rn}$ mass balance will more closely reflect the total volume of groundwater entering the river, whereas $\mathrm{Cl}$ mass balance will more closely reflect the volume of regional groundwater entering the river. This may account for the agreement between groundwater inflows from differential flow gauging and ${ }^{222} \mathrm{Rn}$ mass balance but the poor agreement between differential flow gauging and $\mathrm{Cl}$ mass balance (Fig. 12).

While there is a strong correlation between groundwater discharge estimates from ${ }^{222} \mathrm{Rn}$ mass balance and differential flow gauging, estimates from ${ }^{222} \mathrm{Rn}$ mass balance are greater than those from differential flow gauging during April 2010 and April 2011 (Fig. 12). As ${ }^{222} \mathrm{Rn}$ mass balance will account for the total groundwater discharge, compared to differential flow gauging which accounts for the net groundwater discharge (inflow-outflow), this discrepancy may result from the presence of losing reaches. Sampling during April 2010 and April 2011 occurred after dry periods when the water table was low and losing reaches are more likely to develop (Fig. 13a). In contrast, groundwater discharge estimates during February 2011 given by differential flow gauging were greater than ${ }^{222} \mathrm{Rn}$ mass balance. This discrepancy is likely to reflect unaccounted runoff during increased rainfall in the catchment in the days leading up to sampling (Fig. 13b).

In contrast to the Tambo River, $\mathrm{Cl}$ and ${ }^{222} \mathrm{Rn}$ mass balance give groundwater discharge estimates generally on the same order of magnitude for the Nicholson River, with discharge by $\mathrm{Cl}$ mass balance ranging from 654 to $38300 \mathrm{~m}^{3}$ day ${ }^{-1}$ and discharge by ${ }^{222} \mathrm{Rn}$ mass balance ranging from 88.4 to $61100 \mathrm{~m}^{3} \mathrm{day}^{-1}$. While groundwater near the Tambo River was used to characterise groundwater entering the Nicholson River, these results suggest that the groundwater end members used for mass balance calculations on the Nicholson River may reasonably characterise the groundwater entering the Nicholson River. It also implies that groundwatersurface water interaction along the Nicholson River is less variable than the Tambo River. Under such conditions, uncertainties associated with groundwater characterisation will be reduced.

These results not only highlight the importance of accurately characterising groundwater chemistry for mass balance calculations, but also emphasise the need for groundwater characterisation both regionally and at a high spatial resolution proximal to river systems. This is because nearriver groundwater (which is the water that enters rivers) may 

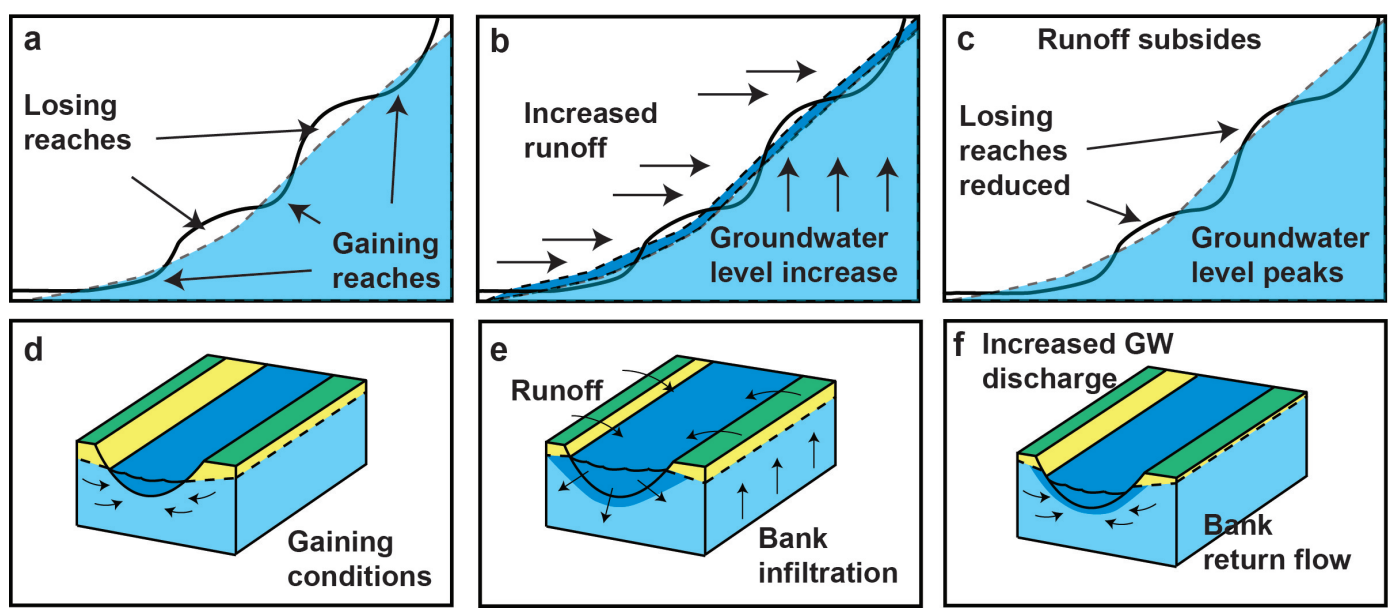

Fig. 13. Schematic representation of the Tambo River profile (solid line), water table (dashed line/light blue shading) and runoff (dark blue shading) under baseflow conditions (a), high-flow conditions (b) and receding conditions (c). River cross sections shown in (d), (e) and (f) for baseflow, high flow and recession, respectively.

have a different and more variable chemistry than regional groundwater.

\subsection{Hydrological drivers}

Groundwater discharge to both the Tambo and Nicholson rivers increased with river discharge. Sampling during highflow periods occurred in the days to weeks following peakflow conditions and is likely to reflect a period in which river discharge is receding while groundwater levels remain high from recharge. Under these conditions high groundwater gradients can form, resulting in increased groundwater discharge (Fig. 13c and f). These results indicate that during high rainfall periods, groundwater levels in the Tambo Catchment can increase quickly enough to maintain a groundwater fraction of $\sim 10 \%$ in the Nicholson and Tambo rivers around 1 week after flooding (e.g. Cey et al., 1998). This indicates that the sand-rich Tertiary and Quaternary aquifers of the region are responsive to rainfall.

While the total groundwater discharge to the Tambo and Nicholson rivers was highest under high-flow conditions, groundwater constituted the highest proportion of river flow under low-flow conditions (Fig. 13a and d). For the Tambo River this occurred during Apri 2010, with groundwater discharge by ${ }^{222} \mathrm{Rn}$ mass balance representing $21.4 \%$ of total river flow. For the Nicholson River, this occurred during September 2010, with groundwater discharge by ${ }^{222} \mathrm{Rn}$ mass balance constituting $18.9 \%$ of river flow. Conversely, groundwater constituted the lowest proportion of river flow under intermediate-flow conditions. This occurred during February 2011 on the Tambo River, with groundwater discharge by ${ }^{222} \mathrm{Rn}$ mass balance constituting $6.8 \%$ of river discharge. For the Nicholson River this occurred during April 2011, with groundwater discharge by ${ }^{222} \mathrm{Rn}$ mass balance constituting $<1 \%$ of river discharge. Both of these sampling campaigns took place during a time of increased rainfall ( $\sim 35 \mathrm{~mm}$ of rainfall in the 4 days leading up to sampling) that followed an extended dry period. As such, it is likely that these periods represent conditions in which the water table was still low while river levels were increasing due to runoff, which would result in reduced groundwater discharge (Fig. 13b and e).

This study shows that, while two rivers within the same aquifer system may vary considerably with respect to discharge volumes, groundwater may still represent a similar proportion of the total river discharge in each case. Further to this, when two rivers occur in the same aquifer system, they are likely to respond similarly under changing rainfall and flow conditions - with relatively low volumes of groundwater providing a high proportion of river discharge under baseflow conditions, rainfall and runoff providing a higher proportion of river discharge during increased rainfall following dry periods, and higher volumes of groundwater representing an intermediate proportion of river flow in the weeks following extensive rainfall in the catchment. This suggests that the lower discharge volumes associated with the Nicholson River are likely to represent the smaller catchment area from which its flow is derived, as opposed to differences in groundwatersurface water interaction.

\section{Conclusions}

By combining the use of chemical and physical tracer methods on the Tambo River, increased groundwater influxes were identified near areas of increased topographic variation, where the potential for higher groundwater-surface water gradient formation is increased. The highest volume of groundwater discharge occurred in the days to weeks following heavy rainfall, when river levels were receding and 
groundwater levels remained high. Groundwater formed the highest proportion of river discharge under baseflow conditions, while rainfall and runoff formed a higher proportion of river flow during periods of increased rainfall that followed from dry periods in the catchment. Discrepancies between ${ }^{222} \mathrm{Rn}$ and $\mathrm{Cl}$ mass balance suggest that spatially variable bank exchange processes can amplify the heterogeneity of $\mathrm{Cl}$ in groundwater-neighbouring rivers, while the equilibration between ${ }^{222} \mathrm{Rn}$ in aquifer sediments with groundwater can reduce the heterogeneity of ${ }^{222} \mathrm{Rn}$ in groundwater. Under these circumstances, extensive spatial groundwater sampling is required to accurately characterise the groundwater $\mathrm{Cl}$ end member. The impact of water exchange between rivers and groundwater on tracers at the bank scale is a process that is still poorly defined, and further investigation into these processes may prove particularly useful in the interpretation of tracer data during future groundwater-surface water studies.

Acknowledgements. We would like to thank Massimo Raveggi and Rachelle Pierson for their help with major ion analyses. Funding for this research was provided by the National Centre for Groundwater Research and Training, and Australian Government initiative, supported by the Australian Research Council and the National Water Commission.

Edited by: Y. Fan

\section{References}

Andersen, M. S. and Acworth, R. I.: Stream-aquifer interactions in the Maules Creek catchment, Namoi Valley, New South Wales, Australia, Hydrogeol. J., 17, 2005-2021, 2009.

Anderson, M. P.: Heat as a ground water tracer, Ground Water, 43, 951-968, 2005.

Anibas, C., Fleckenstein, J. H., Volze, N., Bius, K., Verhoeven, R., Meire, P., and Batelaan, O.: Transient or steady-state? Using vertical temperature profiles to quantify groundwater-surface water exchange, Hydrol. Process., 23, 2165-2177, 2009.

Anibas, C., Buis, K., Verhoeven, R., Meire, P., and Batelaan, O.: A simple thermal mapping method for seasonal spatial patterns of groundwater-surface water interaction, J. Hydrol., 397, 93-104, 2011

Arnott, G. H. and McKinnon, A. D.: Distribution and abundance of eggs of the anchovy, in relation to temperature and salinity in the Gippsland Lakes, Mar. Freshwater Res., 36, 433-439, 1985.

Becker, M. W., Georgian, T., Ambrose, H., Siniscalchi, J., and Fredrick, K.: Estimating flow and flux of ground water discharge using water temperature and velocity, J. Hydrol., 296, 221-233, 2004.

Boano, F., Revelli, R., and Ridolfi, L.: Bedform-induced hyporheic exchange with unsteady flows, Adv. Water Resour., 30, 148-156, 2007.

Boulton, A.: Stream ecology and surface-hyporheic hydrologic exchange: implications, techniques and limitations, Mar. Freshwater Res., 44, 553-564, 1993.

Bureau of Meteorology: Commonwealth of Australia, available at: http://www.bom.gov.au (last access: 11 January 2013), 2012.
Burnett, W. C. and Dulaiova, H.: Radon as a tracer of submarine groundwater discharge into a boat basin in Donnalucata, Sicily, Cont. Shelf Res., 26, 862-873, 2006.

Burnett, W. C., Peterson, R., Moore, W. S., and de Oliveira, J.: Radon and radium isotopes as tracers of submarine groundwater discharge - results from the Ubatuba, Brazil SGD assessment intercomparison, Estuar. Coast. Shelf S., 76, 501-511, 2008.

Burnett, W. C., Peterson, R., Santons, I. R., and Hicks, R. W.: Use of automated radon measurements for rapid assessment of groundwater flow into Florida streams, J. Hydrol., 380, 298-304, 2010.

Cartwright, I., Weaver, T. R., and Tweed, S. O.: Integrating physical hydrogeology, hydrochemistry, and environmental isotopes to constrain regional groundwater flow: Southern Riverine Province, Murray Basin, Australia, in: International Association of Hydrogeologists Special Publication 11, Groundwater Flow Understanding from Local to Regional Scale, edited by: Carrillo, R. J. J. and Ortega, G. M. A., Taylor and Francis, London, UK, 10-134, 2008.

Cartwright, I., Weaver, T. R., Simmons, C. T., Fifield, L. K., Lawrence, C. R., and Chisari, R.: Physical hydrogeology and environmental isotopes to constrain the age, origins, and stability of a low-salinity groundwater lens formed by periodic river recharge: Murray Basin, Australia, J. Hydrol., 380, 203-221, 2010.

Cartwright, I., Hofmann, H., Sirianos, M. A., Weaver, T. R., and Simmons, C. T.: Geochemical and ${ }^{222} \mathrm{Rn}$ constraints on baseflow to the Murray River, Australia, and timescales for the decay of low-salinity groundwater lenses, J. Hydrol., 405, 333-343, 2011.

Cey, E. E., Rudolph, D. L., and Parkin, G. W., and Aravena, R.: Quantifying groundwater discharge to a small perennial stream in southern Ontario, Canada, J. Hydrol., 210, 21-37, 1998.

Chaplin, H. J.: Eastern Victoria Water Table Aquifers, Groundwater Benificial Use Map Series, Department of Conservation and Natural Resources, available at: http://www.water.vic.gov.au/ (last access: 20 March 2013), 1995.

Chen, X. and Chen, X.: Stream water infiltration, bank storage, and storage zone changes due to stream-stage fluctuations, J. Hydrol., 280, 246-264, 2003.

Chen, X., Chen, D. Y., and Chen, X.: Simulation of baseflow accounting for the effect of bank storage and its implication in baseflow separation, J. Hydrol., 327, 539-549, 2006.

Cook, P. G.: Estimating groundwater discharge to rivers from river chemistry surveys, Hydrol. Process., doi:10.1002/hyp.9493, in press, 2012.

Cook, P. G., Favreau, G., Dighton, J. C., and Tickell, S.: Determining natural groundwater influx to a tropical river using radon, chlorofluorocarbons and ionic environmental tracers, J. Hydrol., 277, 74-88, 2003.

Cook, P. G., Lamontagne, S., Berhane, D., and Clark, J. F.: Quantifying groundwater discharge to Cockburn River, southeastern Australia, using dissolved gas tracers ${ }^{222} \mathrm{Rn}$ and $\mathrm{SF}_{6}$, Water Resour. Res., 42, W10411, doi:10.1029/2006WR004921, 2006.

Corbett, D. R., Burnett, W. C., Cable, P. H., and Clark, S. B.: A multiple approach to the determination of radon fluxes from sediments, J. Radioanal. Nucl. Ch., 236, 247-252, 1998.

Cox, M. H., Su, G. W., and Constantz, J.: Heat, Chloride, and Specific Conductance as Ground Water Tracers near Streams, Ground Water, 45, 187-195, 2007. 
Department of Agriculture, Fisheries and Forrestry: available at: http://adl.brs.gov.au/water2010/pdf/catchment2230summary. pdf (last access: 19 November 2012), 2006.

Department of Environment and Primary Inductries: available at: http://vro.dpi.vic.gov.au/dpi/vro/vrosite.nsf/pages/ water-gw-quality-quantity, last access: 5 July 2013.

Durand, P., Neal, M., and Neal, C.: Variations in stable oxygen isotope and solute concentrations in small submediterranean montane streams, J. Hydrol., 144, 283-290, 1993.

Ellins, K. K., Roman-Mas, A., and Lee, R.: Using ${ }^{222}$ Rn to examine groundwater/surface discharge interaction in the Rio Grande de Manati, Puerto Rico, J. Hydrol., 115, 319-341, 1990.

Genereux, D. P. and Hemond, H. F.: Naturally occurring Radon 222 as a tracer for streamflow generation: steady state methodology and field example, Water Resour. Res., 26, 3065-3075, 1990.

Genereux, D. P. and Hemond, H. F.: Determination of gas exchange rate constants for a small stream on Walker Branch Watershed, Tennessee, Water Resour. Res., 28, 2365-2374, 1992.

Genereux, D. P., Hemond, H. F., and Mulholland, P. J.: Use of radon-222 and calcium as tracers in a three-end-member mixing model for streamflow generation on the West Fork of Walker Branch Watershed, J. Hydrol., 142, 167-211, 1993.

Gilfedder, B. S., Hofmann, H., and Cartwright, I.: Novel instruments for in situ continuous ${ }^{222} \mathrm{Rn}$ measurement in groundwater and the application to river bank infiltration, Environ. Sci. Technol., 47, 993-1000, 2012.

Harte, P. and Kiah, R.: Measured river leakages using conventional streamflow techniques: the case of Souhegan River, New Hampshire, USA, Hydrogeol. J., 17, 409-424, 2009.

Hofmann, H., Gilfedder, B. S., and Cartwright, I.: A novel method using a silicone diffusion membrane for continuous ${ }^{222} \mathrm{Rn}$ measurements for the quantification of groundwater discharge to streams and rivers, Environ. Sci. Technol., 45, 8915-8921, 2011.

Jolly, R. L.: Bairnsdale, 1 : 250000 Geological Map Series, Department of Natural Resources and Environment, MDC Fitzroy, Victoria, 1997.

Kalbus, E., Reinstorf, F., and Schirmer, M.: Measuring methods for groundwater - surface water interactions: a review, Hydrol. Earth Syst. Sci., 10, 873-887, doi:10.5194/hess-10-873-2006, 2006.

Kasahara, T. and Wondzell, S. M.: Geomorphic controls on hyporheic exchange flow in mountain streams, Water Resour. Res., 39, 1005, doi:10.1029/2002WR001386, 2003.

Krause, S., Bronstert, A., and Zehe, E.: Groundwater-surface water interactions in a North German lowland floodplain - implications for the river discharge dynamics and riparian water balance, J. Hydrol., 347, 404-417, 2007.

Lambs, L.: Interactions between groundwater and surface water at river banks and the confluence of rivers, J. Hydrol., 288, 312326, 2004.

Lamontagne, S. and Cook, P. G.: Estimation of hyporheic water residence time in situ using ${ }^{222} \mathrm{Rn}$ disequilibrium, Limnol. Oceanogr.-Meth., 5, 407-416, 2007.

Lamontagne, S., Leaney, F. W., and Herczeg, A. L.: Groundwatersurface water interactions in a large semi-arid floodplain: implications for salinity management, Hydrol. Process., 19, 30633080, 2005.
Lamontagne, S., Le Gal La Salle, C., Hancock, G. J., Webster, I. T., Simmons, C. T., Love, A. J., James-Smith, J., Smith, A. J., Kämpf, J., and Fallowfield, H. J.: Radium and radon radioisotopes in regional groundwater, intertidal groundwater, and seawater in the Adelaide Coastal Waters Study area: implications for the evaluation of submarine groundwater discharge, Mar. Chem., 109, 318-336, 2008.

Lerner, D. N., Issar, A. S., and Simmers, I.: Groundwater recharge, a guide to understandin and estimating natural recharge, Rep. 8, International Association of Hydrogeologists, Kenilworth, 1990.

MacKay, H. M. and Schumann, E. H.: Mixing and circulation in the sundays river estuary, South Africa, Estuar. Coast. Shelf S., 31, 203-216, 1990.

Martens, C. S., Kipphut, G. W., and Klump, J. V.: Sediment-water chemical exchange in the coastal zone traced by in situ ${ }^{222}$ Radon flux measurements, Science, 208, 285-288, 1980.

McCallum, J. L., Cook, P. G., Brunner, P., and Berhane, D.: Solute dynamics during bank storage flows and implications for chemical base flow separation, Water Resour. Res., 46, W07541, doi:10.1029/2009WR008539, 2010.

McCallum, J. L., Cook, P. G., Berhane, D., Rumpf, C., and McMahon, G. A.: Quantifying groundwater flows to streams using differential flow gaugings and water chemistry, J. Hydrol., 416, 118-132, 2012.

McCallum, A. M., Andersen, M. S., and Acworth, R. I.: A New Method for Estimating Recharge to Unconfined Aquifers Using Differential River Gauging, Ground Water, doi:10.1111/gwat.12046, in press, 2013.

Mullinger, N. J., Binley, A. M., Pates, J. M., and Crook, N. P.: Radon in Chalk streams: spatial and temporal variation of groundwater sources in the Pang and Lambourn catchments, UK, J. Hydrol., 339, 172-182, 2007.

Mullinger, N. J., Pates, J. M., Binley, A. M., and Crook, N. P.: Controls on the spatial and temporal variability of ${ }^{222} \mathrm{Rn}$ in riparian groundwater in a lowland Chalk catchment, J. Hydrol., 376, 5869, 2009.

Négrel, P., Petelet-Giraud, E., Barbier, J., and Gautier, E.: Surface water-groundwater interactions in an alluvial plain: chemical and isotopic systematics, J. Hydrol., 277, 248-267, 2003.

Negulescu, M. and Rojanski, V.: Recent research to determine reaeration coefficients, Water Res., 3, 189-202, 1969.

Nunes Vaz, R. A., Lennon, G. W., and de Silva Samarasinghe, J. R.: The negative role of turbulence in estuarine mass transport, Estuar. Coast. Shelf S., 28, 361-377, 1989.

O'Connor, D. J. and Dobbins, W. E.: Mechanisms of reaeration in natural streams, T. Am. Soc. Civ. Eng., 123, 641-684, 1958.

Peterson, R. N., Santos, I. R., and Burnett, W. C.: Evaluating groundwater discharge to tidal rivers based on a ${ }^{222} \mathrm{Rn}$ timeseries approach, Estuar. Coast. Shelf S., 86, 165-178, 2010.

Peyrard, D., Delmotte, S., Sauvage, S., Namour, P. H., Gerino, M., Vervier, P., and Sanchez-Perez, J. M.: Longitudinal transformation of nitrogen and carbon in the hyporheic zone of an $\mathrm{N}-$ rich stream: a combined modelling and field study, Phys. Chem. Earth, 36, 599-611, 2011.

Rau, G. C., Andersen, M. S., McCallum, A. M., and Acworth, R. I.: Analytical methods that use natural heat as a tracer to quantify surface water-groundwater exchange, evaluated using field temperature records, Hydrogeol. J., 18, 1093-1110, 2010. 
Rhode, A.: Spring flood: meltwater or groundwater?, Nord. Hydrol., 12, 21-30, 1981.

Ribolzi, O., Andrieux, P., Valles, V., Bouzigues, R., Bariac, T., and Voltz, M.: Contribution of groundwater and overland flows to storm flow generation in a cultivated Mediterranean catchment, quantification by natural chemical tracing, J. Hydrol., 233, 241257, 2000 .

Ruehl, C., Fisher, A. T., Hatch, C., Los Huertos, M., Stemler, G., and Shennan, C.: Differential gauging and tracer tests resolve seepage fluxes in a strongly-losing stream, J. Hydrol., 330, 235248, 2006.

Runkel, R. L.: One-Dimensional Transport with Inflow and Storage (OTIS): A Solute Transport Model for Streams and Rivers, US Geol. Surv. Water Resour. Invest. Rep., 98-4018, 1998.

Santos, I. R. and Eyre, B. D.: Radon tracing of groundwater discharge into an Australian estuary surrounded by coastal acid sulphate soils, J. Hydrol., 396, 246-257, 2011.

Santos, I. R., Peterson, R. N., Eyre, B. D., and Burnett, W. C.: Significant lateral inputs of fresh groundwater into a stratified tropical estuary: evidence from radon and radium isotopes, Mar. Chem., 121, 37-48, 2010.

Silliman, S. E. and Booth, D. F.: Analysis of time-series measurements of sediment temperature for identification of gaining vs. losing portions of Juday Creek, Indiana, J. Hydrol., 146, 131148, 1993.

Sophocleous, M.: Interactions between groundwater and surface water: the state of the science, Hydrogeol. J., 10, 52-67, 2002.
Stacey, M. T., Fram, J. P., and Chow, F. K.: Role of tidally periodic density stratification in the creation of estuarine subtidal circulation. J. Geophys. Res., 113, C08016, doi:10.1029/2007JC004581, 2008.

Stellato, L., Petrellz, E., Terrasi, F., Bellonie, P., Belli, M., Sansone, U., and Celico, F.: Some limitations in using ${ }^{222} \mathrm{Rn}$ to assess river-groundwater interactions: the case of Castel di Sangro alluvial plain (central Italy), Hydrogeol. J., 16, 701-712, 2008.

Tsur, Y. and Graham-Tomasi, T.: The buffer value of groundwater with stochastic surface water supplies, J. Environ. Econ. Manage., 21, 201-224, 1991.

Vandenberg, A. H. M. and Stewart, I. R.: Ordovician terranes of the southeastern Lachlan Fold Belt: stratigraphy, structure and palaeogeographic reconstruction, Tectonophysics, 214, 159-176, 1992.

Victorian Water Resources Data Warehouse: available at: http: //www.vicwaterdata.net/vicwaterdata/home.aspx (last access: 11 January 2013), 2012.

Wagner, B. J. and Harvey, J. W.: Experimental design for estimating parameters of rate-limited mass transfer: analysis of stream tracer studies, Water Resour. Res., 33, 1731-1741, 1997.

Woessner, W. W.: Stream and fluvial plain ground water interactions: rescaling hydrogeologic thought, Ground Water, 38, 423429, 2000. 